\title{
The Dragon's Reach: An Assessment of the People's Republic of China's Expeditionary Capabilities
}

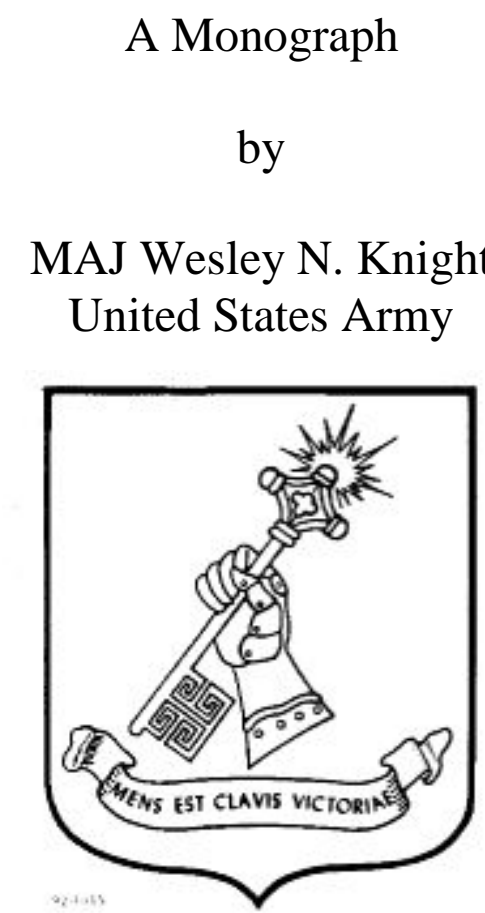

School of Advanced Military Studies

United States Army Command and General Staff College

Fort Leavenworth, Kansas

$$
\text { 2015-01 }
$$

Approved for Public Release; Distribution is Unlimited. 


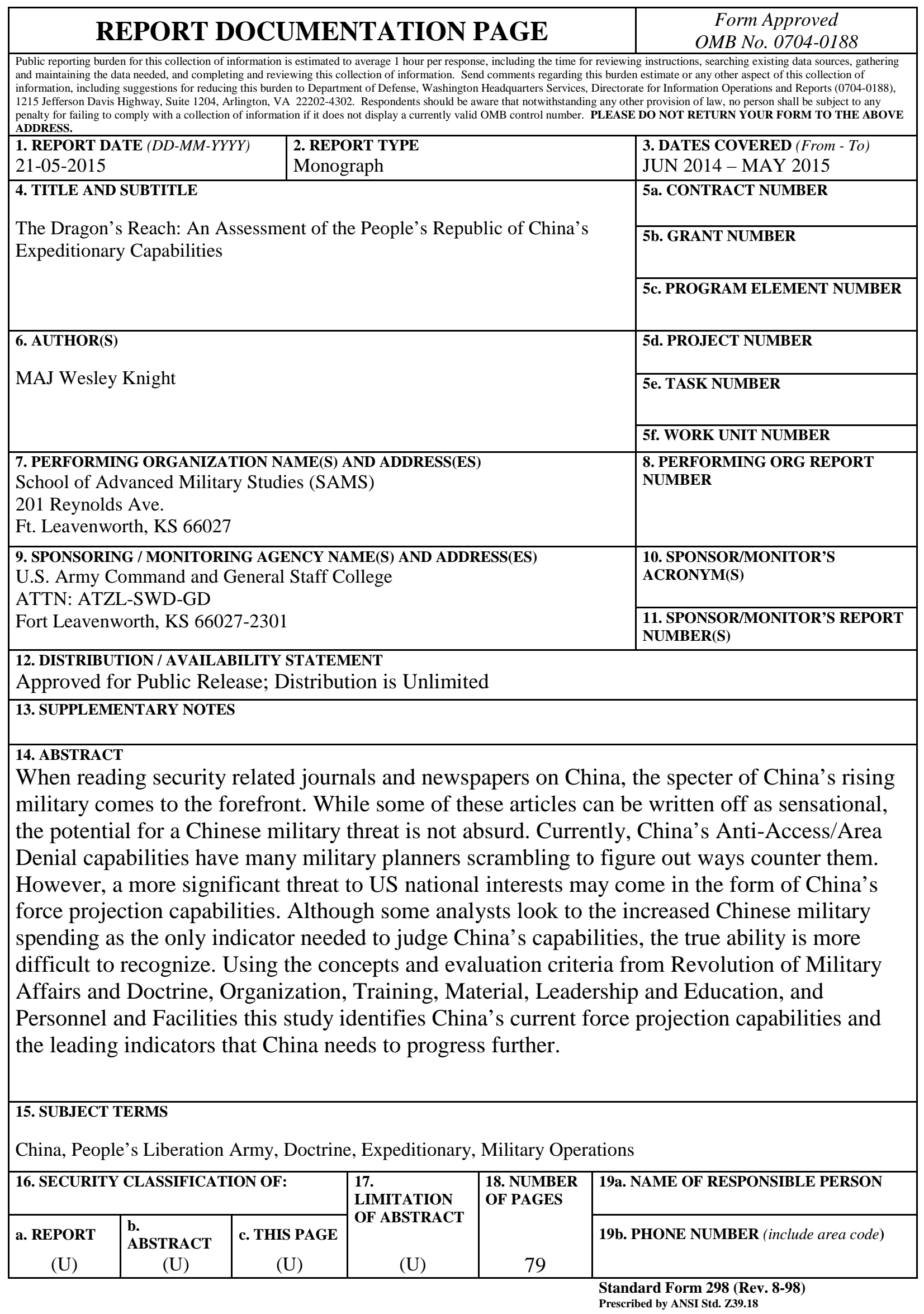




\section{Monograph Approval Page}

Name of Candidate: MAJ Wesley N. Knight

Monograph Title: The Dragon's Reach: An Assessment of the People’s Republic of China’s Expeditionary Capabilities

Approved by:

Monograph Director

Michael D. Mihalka, PhD

Seminar Leader

Holger Draber, COL

, Director, School of Advanced Military Studies

Henry A. Arnold III, COL

Accepted this 21st day of May 2015 by:

Robert F. Baumann, PhD

, Director, Graduate Degree Programs

The opinions and conclusions expressed herein are those of the student author and do not necessarily represent the views of the US Army Command and General Staff College or any other governmental agency. (References to this study should include the foregoing statement.) 


\begin{abstract}
The Dragon's Reach: An Assessment of the People’s Republic of China's Expeditionary Capabilities, by MAJ Wesley N. Knight, 74 pages.

When reading security related journals and newspapers on China, the spectre of China's rising military comes to the forefront. While some of these articles can be written off as sensational, the potential for a Chinese military threat is not absurd. Currently, China's Anti-Access/Area Denial capabilities have many military planners scrambling to figure out ways counter them. However, a more significant threat to US national interests may come in the form of China's force projection capabilities. Although some analysts look to the increased Chinese military spending as the only indicator needed to judge China's capabilities, the true ability is more difficult to recognize. Using the concepts and evaluation criteria from Revolution of Military Affairs and Doctrine, Organization, Training, Materiel, Leadership and Education, and Personnel and Facilities this study identifies China's current force projection capabilities and the leading indicators that China needs to progress further.
\end{abstract}




\section{Contents}

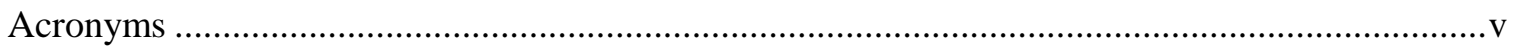

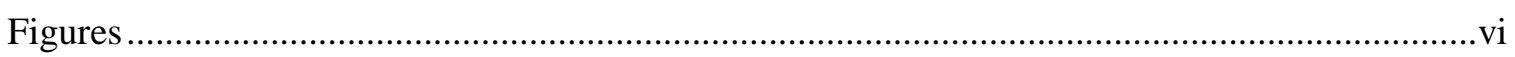

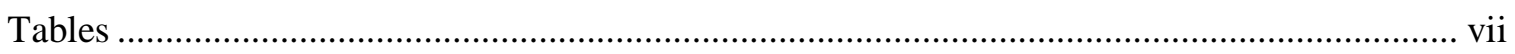

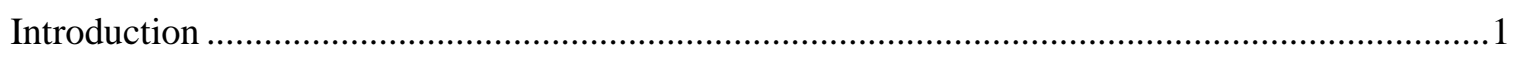

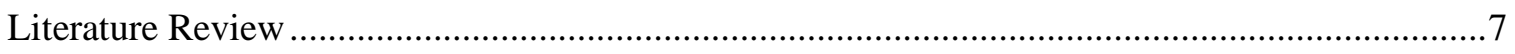

A Chinese Way of Expeditionary Warfare? ................................................................ 15

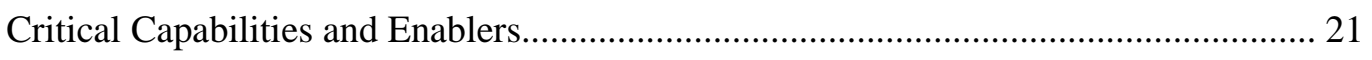

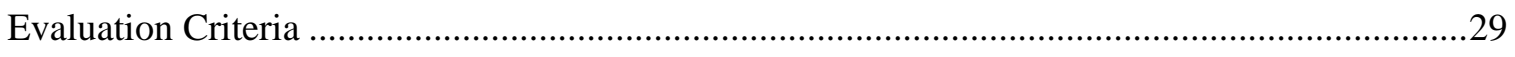

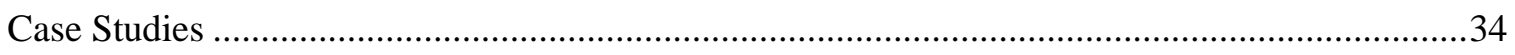

The 2000 British Intervention in Sierra Leone ................................................................ 34

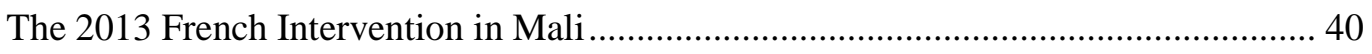

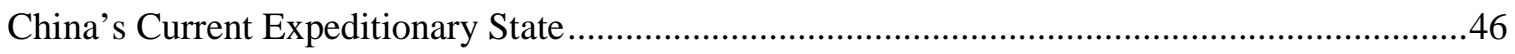

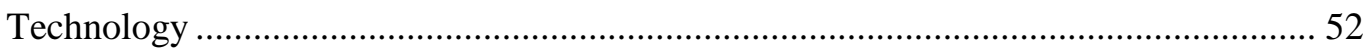

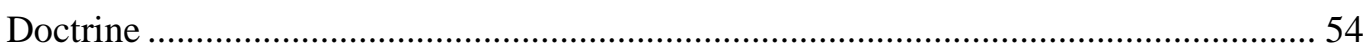

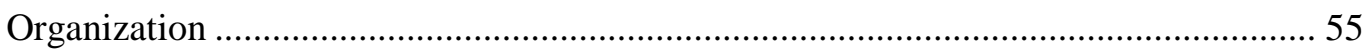

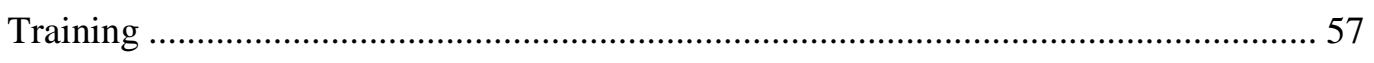

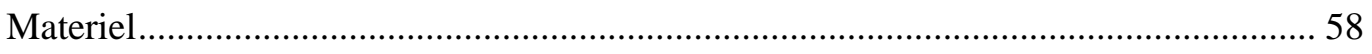

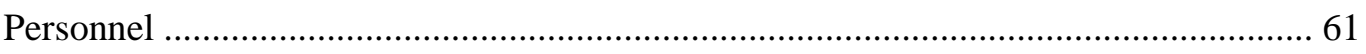

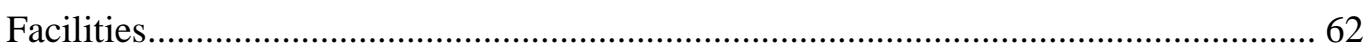

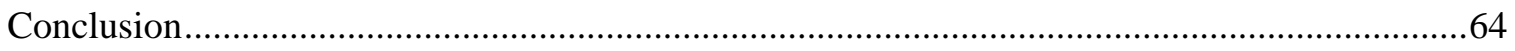

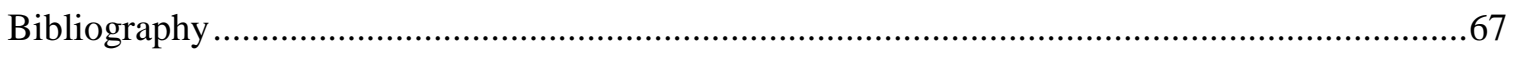




\section{Acronyms}

\begin{tabular}{|c|c|}
\hline $\mathrm{A} 2 / \mathrm{AD}$ & Anti-Access/Area Denial \\
\hline DOTMLPF & $\begin{array}{l}\text { Doctrine, Organization, Training, Materiel, Leadership and Education, Personnel, } \\
\text { and Facilities }\end{array}$ \\
\hline FEO & Forcible Entry Operation \\
\hline FHA & Foreign Humanitarian Assistance \\
\hline ISR & Intelligence, Surveillance, and Reconnaissance \\
\hline JLSD & Joint Logistics Sub-Departments \\
\hline LSM & Landing Ship, Medium \\
\hline LST & Landing Ship, Tank \\
\hline NATO & North Atlantic Treaty Organization \\
\hline NEO & Noncombatant Evacuation Operation \\
\hline PLA & People’s Liberation Army \\
\hline PLAA & People’s Liberation Army - Army \\
\hline PLAAF & People’s Liberation Army - Air Force \\
\hline PLAN & People’s Liberation Army - Navy \\
\hline $\mathrm{PO}$ & Peace Operations \\
\hline RMA & Revolution of Military Affairs \\
\hline RUF & Revolutionary United Front \\
\hline UK & United Kingdom \\
\hline UN & United Nations \\
\hline UNAMSIL & United Nations Mission in Sierra Leone \\
\hline WSB & West Side Boys \\
\hline
\end{tabular}




\section{Figures}

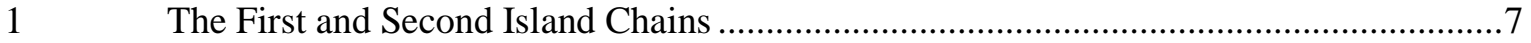

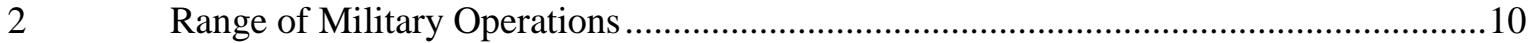

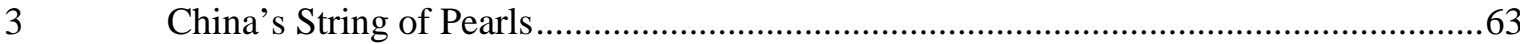




\section{Tables}

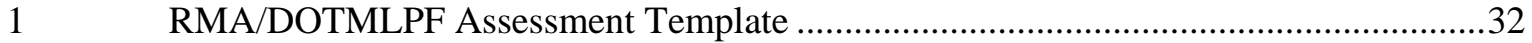

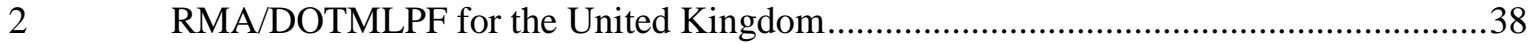

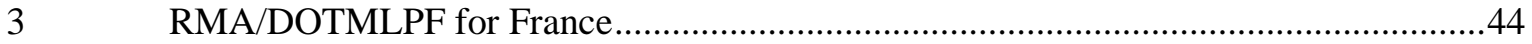




\section{Introduction}

As a global power with global interests, the United States must maintain the credible capability to project military force into any region of the world in support of those interests

—Chairman Joint Chiefs of Staff, Joint Operational Access Concept

The US requirement to project force into any region in the world for their own national interests is no surprise to observers of international affairs. Therefore, attempts by other nations striving to do the same should not come as a surprise. Nations use their diplomatic, economic, information, and military capabilities to project influence to protect or further their national interests abroad. This paper focuses on the military tools of a nation, or more specifically, a nation's ability to project those military forces outside its borders. When this topic of force projection capabilities arises, the attention is usually not on US force projection capabilities, but rather on the increasing military capabilities of the People’s Republic of China. ${ }^{1}$ By scanning US newspapers and journals, one repeatedly sees China’s growing military threat highlighted due to her growing economy, and expanding military technologies come to the forefront. These US headlines evoke the mental images of Chinese forces landing on the shores of neighboring Asian allies and partners expressing their concern that Hawaii and the US West Coast may be in China's reach as well. While these images and headlines may increase sales of these periodicals, the true assessment of China's threat and its potential is more complex than only technologic and economic growth, because moving military forces beyond a nation's borders and continuously supporting them during operations requires a significant amount of time, training, and resources. These sensational headlines and vast military requirements leads one to ask, what are the leading indicators of China's ability to conduct the most intense form of expeditionary operation, a forced entry operations (FEO)? Using US military concepts and evaluation constructs to assess the

${ }^{1}$ Throughout this paper, the use of China refers to the People's Republic of China. 
integration and performance of Chinese equipment, personnel, and organizations, China does not currently possess the capability to conduct a FEO beyond her near seas. However, China does possess adequate capabilities that allow her to conduct FEOs against some regional neighbors within her near seas. ${ }^{2}$ The first set of indicators that shows China's progression towards being able to conduct a successful FEO focuses on acquiring and/or upgrading different equipment such as fourth generation fighters, intelligence, surveillance, and reconnaissance (ISR) platforms, submarines, amphibious assault ships, aircraft carriers, and strategic airlift. The second set of indicators involves the demonstration of sustained logistics support abroad. The final indicator is the Chinese integration of this new and modern equipment with her organizations while conducting a large-scale expeditionary mission or exercise beyond her near seas.

Western fears of China originated with the establishment of a communist government under Mao Zedong in 1949. Since that time, the United States and China have had a very complex relationship that ranged from open armed conflict during the Korean War to close trading partners today. ${ }^{3}$ While one may assume the relationship has improved dramatically due to the vast amount of trade between the United States and China, there is still a growing concern within the US security apparatus over China's intentions. ${ }^{4}$

\footnotetext{
${ }^{2}$ Near seas refers to the nations and bodies of water within the First Island Chain. The
} First Island Chain is a line of islands that include Kurile Islands, Japan, the Ryukyu Islands, Taiwan, the Philippine Islands, and Indonesia. GlobalSecurity.org, "People’s Liberation Navy Offshore Defense,” November 07, 2011, accessed April 09, 2015, http://www.globalsecurity.org/ military/world/china/plan-doctrine-offshore.htm.

${ }^{3}$ US Department of State, Office of the Historian, "Chronology of U.S.-China Relations, 1784-2000,” US Department of State, accessed October 30, 2014, https://history.state.gov/ countries/issues/china-us-relations.

4 Jabara et al., The Year in Trade 2013: Operation of the Trade Agreements Program (Washington, DC: US International Trade Commission, July 2014), accessed October 13, 2014, http://www.usitc.gov/publications/332/pub4481.pdf. 
These primary concerns revolve around China's lack of transparency and openness in regards to her increased military expenditures. ${ }^{5}$ Additionally, China’s aggressive nature such as impeding movement of US Navy vessels in the South China Sea, as well as a Chinese fishing trawler ramming a Japanese Coast Guard vessel in the East China Sea further increases concerns over China's increased military expenditures. ${ }^{6}$ The combination of this growing military threat and uncertainty possesses significant implications for the United States.

These implications for the US are the arms race between its allies and the provocative nature of China's government that could lead to an armed conflict. ${ }^{7}$ By not knowing China's intentions, US allies and partners respond by increasing the capabilities of their forces and strengthening security relationships with other nations. China observes these actions and responds with more spending, thus leading to a security dilemma. ${ }^{8}$ In addition to this spending, China's increasing aggressiveness in the South and East China Sea pushes tensions higher in the region. China uses her maritime law enforcement and naval forces to monitor, harass, and intimidate

${ }^{5}$ Department of Defense, Quadrennial Defense Review 2014 (Washington, DC: Department of Defense, March 4, 2014), accessed September 30 2014, http://www.defense. gov/pubs/2014_Quadrennial_Defense_Review.pdf, 4.

${ }^{6}$ Howard W. French, “China’s Dangerous Game,” The Atlantic, October 13, 2014, accessed March 31, 2015, http://www.theatlantic.com/magazine/archive/2014/11/chinasdangerous-game/380789/.

${ }^{7}$ Unless specified, the use of "US allies" refers to the security treaty partners of Japan, South Korea, Thailand, Philippines, and Australia.

${ }^{8}$ US Congress, House, Testimony of Dr. Larry Wortzel before the Armed Services Committee, US House of Representatives, November 20, 2013, 2013 Annual Report to Congress: China's Military Modernization, U.S.-China Security Relations, and China's Cyber Activities, US-China Economic and Security Review Commission, accessed September 30, 2014, http://www.uscc.gov/Testimonies_Speeches/2013-annual-report-congress-china\%E2\%80\%99smilitary-modernization-us-china-security, 1-2. International Relations Professor Robert Jervis defines Security Dilemma as a situation in which attempts made by one nation to improve its security may decrease another state's security that leads to heightened tensions or conflict. Robert Jervis, “Dilemmas About Security Dilemmas,” Security Studies 20, no. 3 (July 2011): 416. 
many nations’ military and government air and sea vessels operating in the near seas area. ${ }^{9}$ These actions potentially set the stage for an armed conflict in the region with US allies, forcing the United States to respond. Finally, Admiral Samuel Locklear, Commander of US Pacific Command, assessed that China, through its military modernization, aims to deny the United States access to the Western Pacific and provide China with the ability to support its maritime claims in the region. ${ }^{10}$ This capability would allow China to threaten US economic and security interests in the region, and elevate tensions to those reminiscent of the relationship between the Soviet Union and the United States during the Cold War. All of these factors combined create a very precarious political and military situation in the Far East that the US government and its allies must navigate.

US decision-makers see the Asian-Pacific security environment and now must contemplate the necessary military spending, security agreements, and diplomatic relations based on the interpretations or assessments of China's actions. The focus of interpreting China's actions tends to involve the specific attribute that concerned Admiral Locklear's main concern that is China's Anti-Access/Area Denial capabilities (A2/AD).${ }^{11}$ While the focus is on A2/AD, China's

\footnotetext{
${ }^{9}$ US Congress, House, Testimony of Vice Chairman Dennis C. Shea before the Armed Services Committee, US House of Representatives, November 20, 2013, 2013 Annual Report to Congress: China's Maritime Disputes in the East and South China Seas, and the Cross-Strait Relationship, US-China Economic and Security Review Commission, accessed September 30, 2014, http://www.uscc.gov/Testimonies_Speeches/2013-annual-report-congress-china \%E2\%80\%99s-maritime-disputes-east-and-south-china-seas, 3.

${ }^{10}$ US Congress, Senate, Statement of Admiral Samuel J. Locklear, U.S. Navy Commander, U.S. Pacific Command Before The Senate Committee On Armed Services on U.S. Pacific Command Posture, March 25, 2014, accessed September 30, 2014, US Senate Committee on Armed Services, http://www.armed-services.senate.gov/imo/media/doc/Locklear_03-2514.pdf, 9-10.
} 
ability to project her military beyond her near seas is also a growing concern. China's current and projected military capabilities serve as the focus of this paper due to her significant diplomatic, economic, and military implications. If China has the capability to project sufficient military power beyond its borders and near seas, the strategic implications to US security and economic interests in the region would be very profound. ${ }^{12}$ These security and economic effects reinforce the need to understand and predict China's capabilities to inform US national level decisions regarding defense alliances, basing, weapons procurement, and training.

This monograph attempts to add to the strategic security discussion by identifying China’s current and future military power projection capabilities, as well as potential leading indicators of these capabilities. The first step will be to define key terms and concepts using US military doctrine and security studies to reduce ambiguity and confusion. Next, reviewing US government and think-tank security reports, and Chinese defense papers, the author will attempt to describe a Chinese way of expeditionary warfare. Subsequently, a review of US and foreign military doctrine will be used to find commonly accepted key capabilities required to project military power. Following the identification of key capabilities, the author will describe the evaluation framework consisting of Revolution of Military Affairs (RMA) and doctrine, organization, training, materiel, leadership and education, personnel, and facilities (DOTMLPF). Using this evaluation framework, the author will conduct a qualitative case study methodology of the British military intervention in Sierra Leone in 2000 and the French military intervention in Mali in 2013 to validate the evaluation criterion. The information gleaned from these two case

${ }^{11}$ Anti-Access/Area Denial (A2/AD) are capabilities aimed at slowing movement of military forces into a theater of operations and degrading the operational capabilities of their forces once they are in theater. For more information on A2/AD, see Air-Sea Battle Office, AirSea Battle: Service Collaboration to Address Anti-Access \& Area Denial Challenges, May 2013, accessed October 30, 2014, http://www.defense.gov/pubs /ASB-ConceptImplementationSummary-May-2013.pdf, 2.

${ }^{12}$ US Congress, Senate, Statement of Admiral Samuel J. Locklear, 10-11. 
studies will show key enablers of those capabilities necessary to conduct contemporary expeditionary operations. Finally, this paper will provide an assessment of China's ability to project military power and indicators that show an increase in those power projection capabilities. The conclusion from this analysis is that China's lack of certain key enablers prevents her from achieving the necessary capabilities to project military power beyond a limited crisis response and contingency operation phase past the first island chain. Until China gains those key enablers through improvement in technology, organization, materiel, personnel, and facilities, she will not be able to conduct major operations and campaigns. However, China currently possesses sufficient capabilities to conduct combat operations on varying scales within range of her land based air support. 


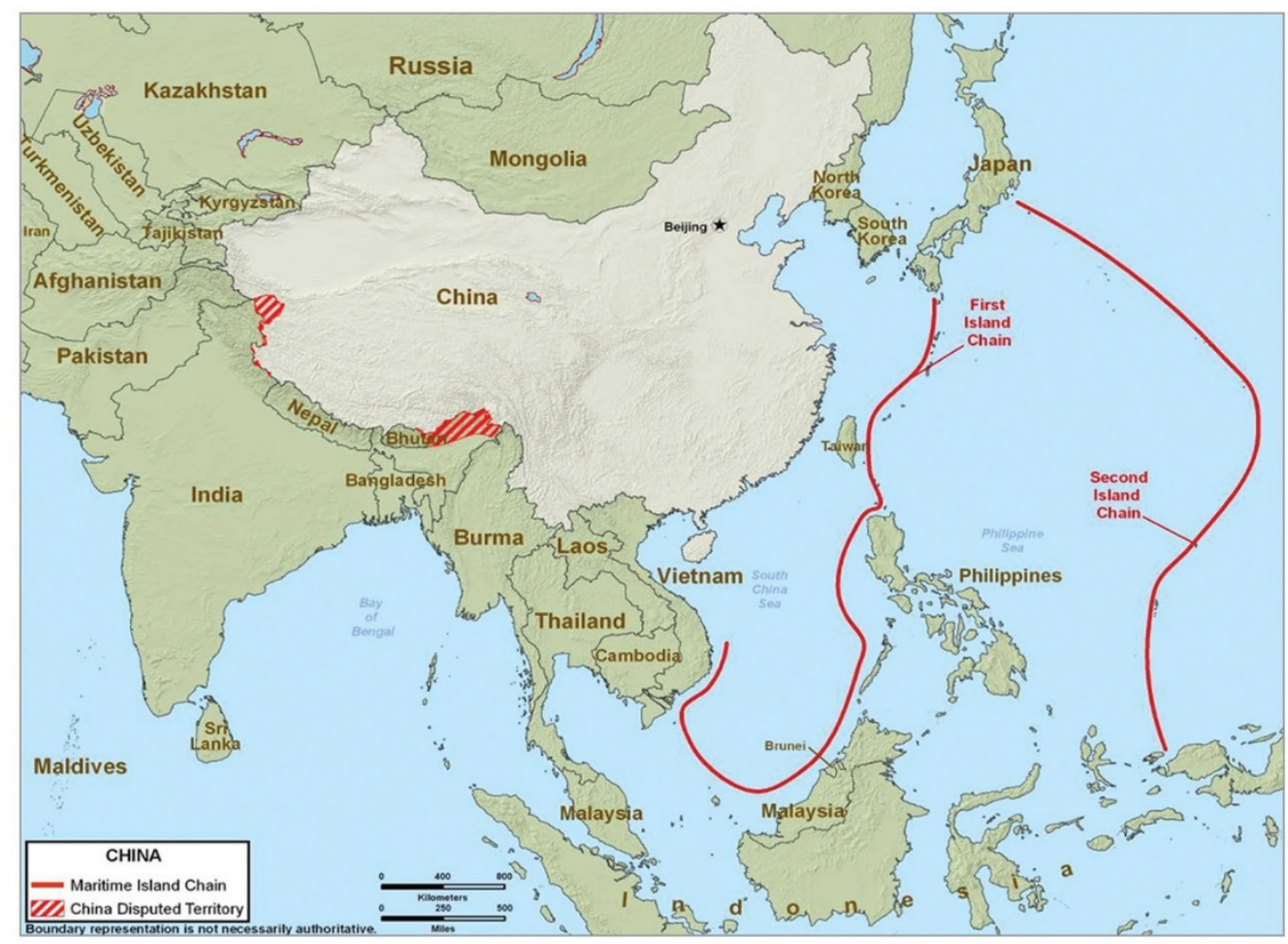

Figure 1. The First and Second Island Chain

Source: Perry-Castañeda Library Map Collection, March 25, 2009, accessed April 16, 2015,http://www.lib.utexas.edu/maps/middle_east_and_asia/china_first_and_second_island _chains_2009.jpg.

\section{Literature Review}

When conducting a review of applicable works written on a nation's ability to project military power beyond its borders, the great deal of literature written by security experts from around the world can easily overwhelm a researcher. This large amount of information makes deciphering the intentions, bias, and knowledge bases of security experts more difficult. Additionally, many of these experts use different terms for similar concepts. To reduce difficulties, official government documents and reports such as doctrine, lessons learned, and after action reviews will serve as the keystone documents to assess the key capabilities required for expeditionary operations for this paper. US, British, and Australian doctrine will provide 
common terms and concepts needed to describe expeditionary capability requirements. In addition to these doctrinal publications, government testimony and reports allow one to deduce key capabilities and enablers necessary to conduct expeditionary operations. The next step in the literature review will center on discerning a Chinese way of expeditionary warfare to identify commonalities to Western doctrine and security studies. These doctrines and security studies will then identify the key capabilities and the enablers necessary to conduct expeditionary operations successfully.

As a key idea of expeditionary operations, the term power projection is identified in US 2012 Joint Operational Access Concept (JOAC) as, "the ability of a nation to apply all or some of its elements of national power (political, economic, informational, or military) to rapidly and effectively deploy and sustain forces in and from multiple dispersed locations to respond to crises, to contribute to deterrence, and to enhance regional stability." ${ }^{13}$ While all nations possess varying degrees of elements of national power, the focus of this paper will primarily be on the military aspect of national power. The US Department of Defense defines the specific military component of the elements of national power as force projection. ${ }^{14}$ While very similar to power projection, force projection focuses entirely on the military aspect of national power and its

${ }^{13}$ Chairman Joint Chiefs of Staff, Joint Operational Access Concept (JOAC), ver. 1 (Washington, DC: Government Printing Office, January 17, 2012), accessed September 30, 2014, http://www.defense.gov/pubs/pdfs/JOAC_Jan\%202012_Signed.pdf, 1-2.

${ }^{14}$ Joint Chiefs of Staff, Joint Publication 3-35, Deployment and Redeployment Operations (Washington, DC: Government Printing Office, January 31, 2013), accessed September 30, 2014, http://www.dtic.mil/doctrine/new_pubs/jp3_35.pdf, GL 8. 
ability to project the “military instrument” from the United States or another location to accomplish a given task or mission. ${ }^{15}$

With force projection now defined, there is still a wide range of military actions that involve force projection. When discussing military action, any use of military force falls within this larger scope. While potentially damaging with a significant propaganda effect, a single strike from a naval, air, or ballistic missile asset would probably be minimal and fail to achieve any specific strategic objective. ${ }^{16}$ Therefore, the scope of military actions being referenced in this paper ranges from deploying a small unit as part of a training exercise for a limited duration to a large-scale invasion and occupation such as Operation Overlord in $1944 .{ }^{17}$ To capture this vast range of operations, US joint doctrine describes military operations as, “varying in scope, purpose, and conflict intensity” and include many different operations. ${ }^{18}$ Figure 2 shows the graphical portrayal of the US range of military operation. ${ }^{19}$ This range of military operations is divided into three categories: military engagement, security cooperation, and deterrence; crisis

${ }^{15}$ Joint Chiefs of Staff, Joint Publication 1-02, Department of Defense Dictionary of Military and Associated Terms (Washington, DC: Government Printing Office, November 8, 2010, as amended through January 2015), accessed August 13, 2014, http://www.dtic.mil/ doctrine/new_pubs/jp3_0.pdf, 98. Force projection is the ability to project the military instrument of national power from the United States or another theater, in response to requirements for military operations.

16 These effects are limited to conventional munitions and do not concern nuclear, biological, or chemical weapons. Additionally, a military strike that creates a natural disaster such as striking a dam or oil tanker is not considered.

${ }^{17}$ Operation Overlord consisted of over 2,700 vessels, 1,900 landing craft, an initial wave of 130,000 soldiers, 2,000 tanks and another 1,200 vehicles on top of the massive air and sea operations going on at the same time around Normandy. Paul M. Kennedy, Engineers of Victory: The Problem Solvers Who Turned the Tide in the Second World War (New York: Random House, 2013), 250.

${ }^{18}$ Joint Chiefs of Staff, Joint Publication (JP) 3-0, Joint Operations (Washington, DC: Government Printing Office, August 11, 2011), accessed August 13, 2014, http://www.dtic.mil/ doctrine/new_pubs/jp3_0.pdf, V-1.

${ }^{19}$ Ibid. 
response and limited contingency operations; and major operations and campaigns. ${ }^{20}$ While all of these categories include operations that may fall within combat, the scale and duration of combat operations increases from its lowest point in the military engagement, security cooperation, and deterrence category and progresses into the largest scale and duration in terms of combat with major operations and campaigns. These three categories serve as stepping stones to show a nation's progression from operations involving little to no combat all the way to full combat operations. Additionally, each category will be divided to show specific missions and the capabilities required to successfully conduct each mission.

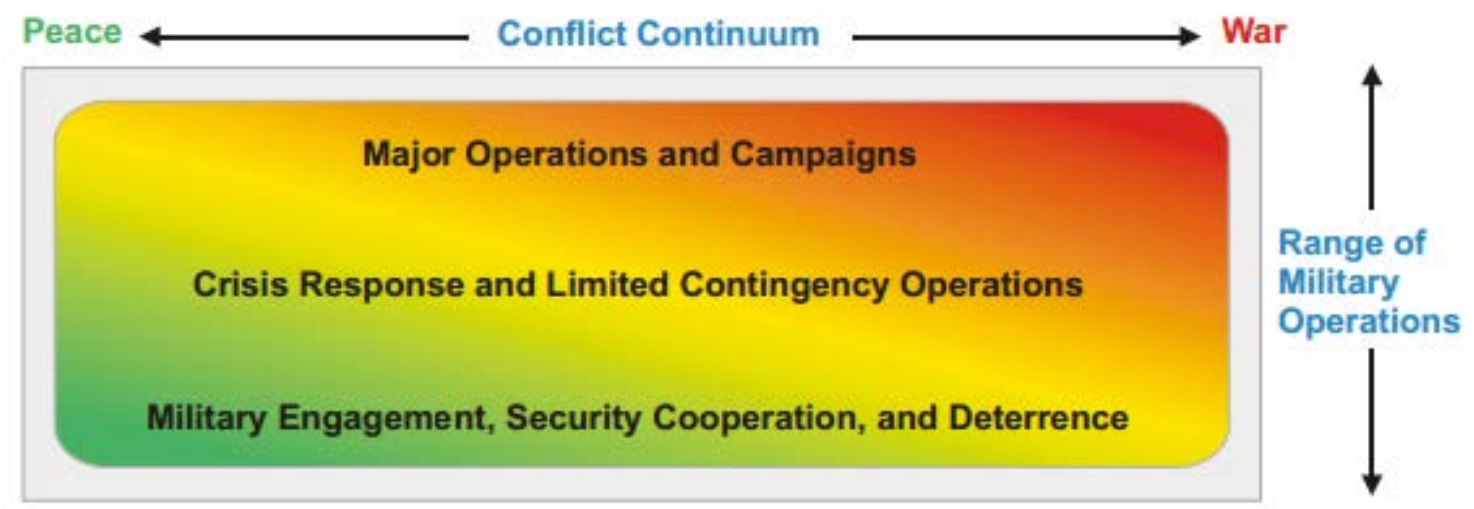

Figure 2. Range of Military Operations

Source: Joint Chiefs of Staff, Joint Publication 3-0, Joint Operations (Washington, DC: Government Printing Office, August 11, 2011), accessed August 13, 2014, http://www.dtic.mil/ doctrine/new_pubs/jp3_0.pdf, V-1.

The first category of military activities and operations is military engagement, security cooperation, and deterrence. This category requires a lower level of force projection capabilities

${ }^{20}$ Joint Chiefs of Staff, Joint Publication (JP) 3-0, Joint Operations (Washington, DC: Government Printing Office, August 11, 2011), accessed August 13, 2014, http://www.dtic.mil /doctrine/new_pubs/jp3_0.pdf, V-1. 
and sophistication and will serve as the first step for a nation along the increasingly difficult range of military operations. ${ }^{21}$ Within this category, the typical operations are smaller in scale and are less likely to lead to combat than in the other two categories. ${ }^{22}$ Currently, China conducts many missions that are part of military engagement, security cooperation, and deterrence such as enforcing exclusion zones, combatting terrorism, and protection of shipping. For example, China already conducts anti-piracy operations in the Gulf of Aden demonstrating that she can accomplish this range of operations. ${ }^{23}$ Because China already has the force projection capability to conduct this category of military operations, this paper will not assess this category.

The next stage along the continuum of military operations is the crisis response and limited contingency operations. Crisis response and limited contingency operations range from small-scale, limited duration operations at one end to larger scale, longer duration operations that may include combat operations. ${ }^{24}$ These operations include non-combatant evacuation operations (NEO), peace operations (PO), foreign humanitarian assistance (FHA), and strikes and raids. ${ }^{25}$ In addition to that, there are operations that fall under the heading of homeland defense and defense support of civil authorities. These operations will not be included in the assessment, as they do not add to the analysis of force projection.

${ }^{21} \mathrm{JP} 3-01, \mathrm{~V}-2$.

22 JP 3-0, V-11.

${ }^{23}$ Andrew S. Erickson, “Chinese Sea Power in Action: The Counterpiracy Mission in the Gulf of Aden and Beyond," in The PLA at Home and Abroad: Assessing the Operational Capabilities of China's Military, ed. Roy Kamphausen, David Lai, and Andrew Scobell (Carlisle, PA: Strategic Studies Institute, US Army War College, 2010), 295-296.

\footnotetext{
${ }^{24} \mathrm{JP} 3-01, \mathrm{~V}-2$.

${ }^{25}$ Ibid., V-20-27.
} 
NEOs are the use of military forces to assist the government in removing its citizens from locations in an unsafe foreign nation. ${ }^{26} \mathrm{NEO}$ is smaller in scale and duration with very limited objectives, thus providing a good starting point for assessing expeditionary operations, as NEOs are typically smaller and shorter than the other operations in this category. ${ }^{27}$ Depending on the operational environment, a state can conduct a NEO in a permissive environment where the host nation allows access, or an uncertain or hostile environment that may require a larger scale force projection, but one that is still below the threshold of major combat operations and campaigns. ${ }^{28}$ In addition to US doctrine, Australian military doctrine adds the concept of trying to maintain a reduced footprint. The US NEO in Somali in 1991 provided a good example of these doctrinal concepts. The scale was relatively small in that it primarily involved only two US naval ships, twelve helicopters, and a sixty-man force to evacuate the 281 people, with a duration of only two days. ${ }^{29}$ This small-scale and limited duration highlights the US and Australian doctrines of conducting a NEO in an unknown environment with a small footprint with no combat actions being used during the course of the operation.

The next step along the continuum of operations within the crisis response and limited contingences operations category is PO. As defined by US doctrine, PO consists of US military forces partnering with domestic and international agencies, and other militaries to contain conflict, bring about peace, and "facilitating the development of reconciliation and rebuilding,

${ }^{26}$ Joint Chiefs of Staff, Joint Publication (JP) 3-68, Noncombatant Evacuation Operations (Washington, DC: Government Printing Office, December 23, 2010), accessed August 13, 2014, http://www.dtic.mil/doctrine/new_pubs/jp3_68.pdf, 11.

${ }^{27}$ Ibid., I-1.

${ }^{28}$ JP 3-68, I-5.

${ }^{29}$ Adam B. Siegel, Eastern Exit: The Noncombatant Evacuation Operation (NEO) from Mogadishu, Somalia, in January 1991 (Alexandria, VA: Center for Naval Analyses, 1991), v, 2. 
while helping transition to a legitimate governance.”30 North Atlantic Treaty Organization (NATO) doctrine echoes US doctrine for peace operations under the term of peace support operations, but remains consistent with the overall concept of restoring or maintaining the peace. ${ }^{31}$ While typically limited in scale, the duration for these operations can be lengthy. For example, United Nation Security Council Resolution 1270 established the peacekeeping force for Sierra Leone in 1999, where it lasted for six years, and included over seventeen thousand military personnel at its height. ${ }^{32}$

The next operation within crisis and limited contingency is FHA. FHA are operations conducted outside the United States with a limited scope and duration aimed at relieving or reducing suffering, disease, hunger, or privation. ${ }^{33}$ While using disaster relief operations vice FHA, the United Kingdom (UK) agrees with US doctrine that civilian organizations such as the International Red Cross are the lead organization, and the military will serve in a secondary role. ${ }^{34}$ Although these organizations will lead, they sometimes do not possess the necessary equipment or expertise to support these operations and require military support. Japan’s

${ }^{30} \mathrm{JP} 3-0, \mathrm{~V}-22$.

${ }^{31}$ North Atlantic Treaty Organization, Allied Joint Publication 3, Allied Joint Doctrine for the Conduct of Operations, ed. B (Brussels, Belgium: NATO Standardization Agency, March 2011), accessed February 5, 2015, http://nso.nato.int/nso/zPublic/ap/ajp-3(b).pdf, 1-5.

${ }^{32}$ United Nations Security Council, "Sierra Leone - UNAMSIL - Facts and Figures," 2005, United Nations, accessed February 12, 2015, http://www.un.org/en/peacekeeping/ missions/past/unamsil/facts.html.

33 Joint Chiefs of Staff, Joint Publication (JP) 3-29, Foreign Humanitarian Assistance (Washington, DC: Government Printing Office, January 3, 2014), accessed February 12, 2015, http://www.dtic.mil/doctrine/new_pubs/jp3_29.pdf, I-1.

${ }^{34}$ Chiefs of Staff, Joint Doctrine Publication 3-52, Disaster Relief Operations, 2nd ed. (Shrivenham, England: Ministry of Defence, 2008), accessed November 4, 2014, https://www.gov.uk/government/uploads/system/uploads/attachment_data/file/43340/jdp3522nde d.pdf, 4-2. 
earthquake and subsequent tsunami resulted in over twenty thousand military personnel, 140 aircraft, and at least twenty ships sent in support of the FHA. ${ }^{35}$

The final operations conducted within the crisis and limited contingency category are strikes and raids. Strikes are attacks aimed at damaging or destroying a specific objective or capability, tending to be tactical in ways and means. ${ }^{36}$ The raid temporarily seizes an area with a pre-determined and planned withdrawal after a certain amount of time. ${ }^{37}$ Strikes and raids are the first operations discussed that are designed to conduct combat actions. These operations are very limited in duration; however, the scale varies depending on the specific purpose of the operation and the near certainty of enemy opposition. The US raid on Grenada shows the limited duration and varied scales of force through the operation involving over eight thousand military personnel, countless sorties, and extensive combat that lasted only ten days. ${ }^{38}$

The final category of military operations is major operations and campaigns. ${ }^{39}$ While these operations do not always involve combat, the scale and duration of these operations are very large. ${ }^{40}$ The specific type of operation that captures the complexity, breadth of joint training and resources, and risk required to conduct these operations are FEOs. ${ }^{41}$ FEOs are vital to meeting the

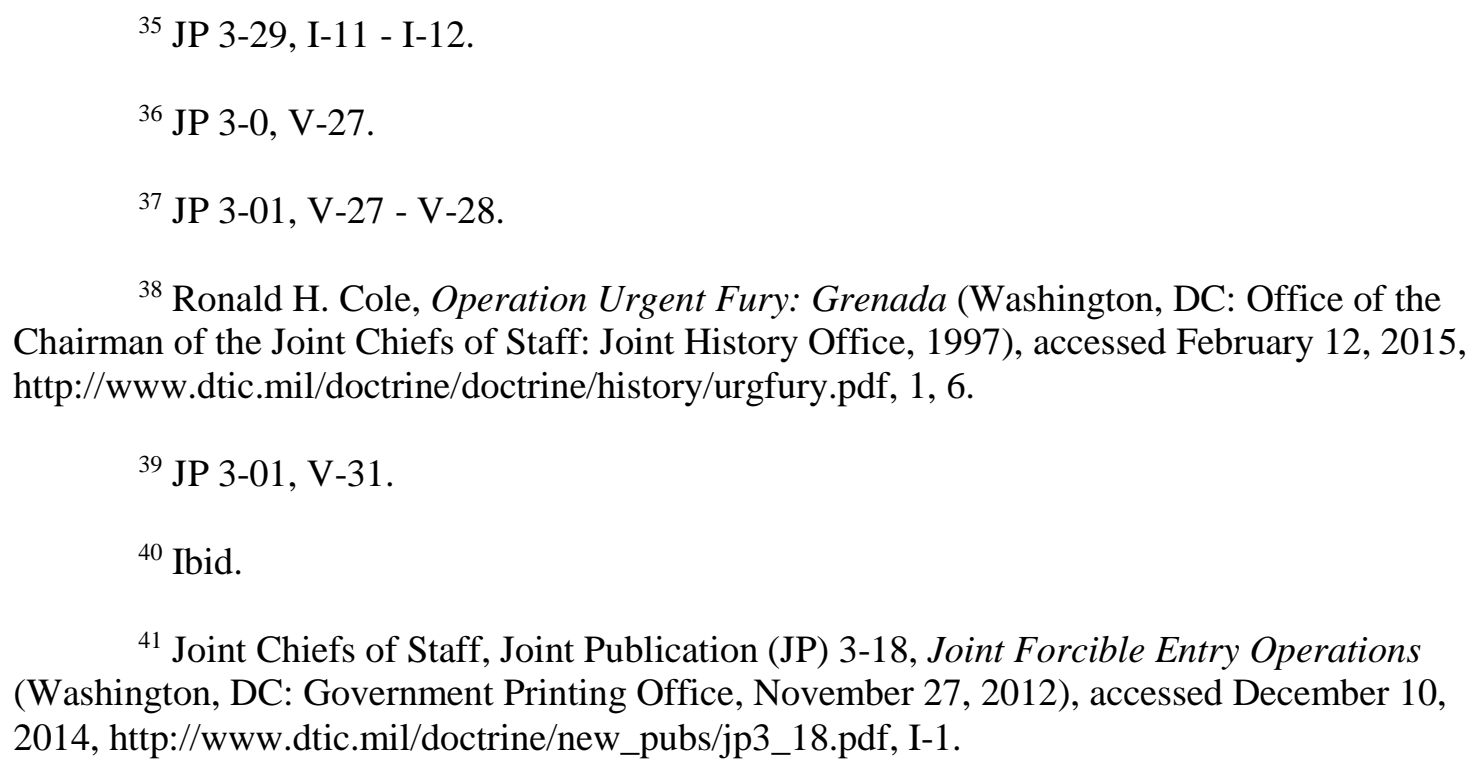

${ }^{38}$ Ronald H. Cole, Operation Urgent Fury: Grenada (Washington, DC: Office of the Chairman of the Joint Chiefs of Staff: Joint History Office, 1997), accessed February 12, 2015, http://www.dtic.mil/doctrine/doctrine/history/urgfury.pdf, 1, 6.

${ }^{39}$ JP 3-01, V-31.

${ }^{40}$ Ibid.

${ }^{41}$ Joint Chiefs of Staff, Joint Publication (JP) 3-18, Joint Forcible Entry Operations (Washington, DC: Government Printing Office, November 27, 2012), accessed December 10, 2014, http://www.dtic.mil/doctrine/new_pubs/jp3_18.pdf, I-1. 
US National Military Strategy of deterrence and policy enforcement as these operations ensure the US military can gain access into any area in the world..$^{42}$ This type of operation seizes and holds lodgments against enemy forces with the usual purpose of securing a base for follow-on operations. ${ }^{43}$ A previously mentioned example that serves as a standard-bearer of FEOs is Operation Overlord. Operation Overlord consisted of over 2,700 vessels, 1,900 landing craft, an initial wave of 130,000 soldiers, 2,000 tanks and another 1,200 vehicles on top of the massive air campaign and naval sea control operations going on at the same time around Normandy. ${ }^{44}$

\section{A Chinese Way of Expeditionary Warfare?}

Now that key terms and concepts are defined, the author will attempt to identify any concepts or enablers critical to the Chinese way of expeditionary warfare. Unlike the review of the previous doctrine, this review focuses primarily on materiel gathered from the US government, think tanks, and Chinese Defense White Papers. The reliance on these few sources for such an important topic is due to the lack of official published Chinese doctrine. Additionally, most sources appear to be professional Chinese military journals written in Chinese, forcing the author to rely on translations captured in the sources listed above. While there is no Chinese expeditionary doctrine available, one can pull some key points from the understanding of the Chinese concepts of force projection. In a review on China and her military force development, Anthony Cordesman of the Center for Strategic and International Studies provided a detailed analysis of China’s military strategy that offers some insight into the Chinese expeditionary way of war. He describes China's military concepts in three hierarchical domains: strategic doctrine,

\footnotetext{
42 JP 3-18, I-2.

${ }^{43}$ Ibid., I-1.

${ }^{44}$ Kennedy, 250.
} 
campaign doctrine, and service strategy. ${ }^{45}$ Cordesman further divides strategic doctrine into three overarching military concepts of active defense, local war under conditions of informatization, and people's war. ${ }^{46}$ Active defense is the focus on defending national sovereignty and territorial integrity, while being prepared to respond to any attack. ${ }^{47}$ While this is stated to be defensive in nature only with the attack coming in the form of a response to a foreign attack, Cordesman points out from analyzing The Science of Military Strategy that while strategically defensively oriented, the operational posture would be offensive to adequately stop an enemy and then defeat them. ${ }^{48}$ He further emphasizes that an attack that triggers a Chinese military response does not need to be a military action, and could be a political or economic action. ${ }^{49}$ This operational offensive capability means that China is not solely oriented at only maintaining the ability to affect its near shores and territories, but must be able to attack the enemy wherever she needs to in order to guarantee her sovereignty and territorial integrity.

The next concept is local war under condition of informatization, which focuses on a

${ }^{45}$ Anthony Cordesman, Chinese Military Modernization and Force Development: Chinese and Outside Perspectives (Washington, DC: Center for Strategic and International Studies, July 2, 2014), accessed December 7, 2014, http://csis.org/files/publication/140702_ Chinese_MilBalance.pdf, 123.

${ }^{46}$ Ibid., 123.

${ }^{47}$ The People's Republic of China, Chinese Defense White Paper, The Diversified Employment of China's Armed Forces (Beijing, China: Information Office of the State Council, April 16, 2013), accessed February 3, 2015, http://eng.mod.gov.cn/Database/WhitePapers/ 2012.htm, sect. I.

${ }^{48}$ Cordesman, 124. Additionally, The Science of Military Strategy are Chinese military strategy books published by the PLA's Academy of Military Science, therefore, this source is an official Chinese publication.

${ }^{49}$ Ibid., 124. 
dependence on information technology and the belief that wars will be limited in scope, duration, and political objectives. ${ }^{50}$ Cordesman further specifies that informatization is the use of advanced computer systems, information technology, and communication networks to gain an advantage over an enemy to defeat him. ${ }^{51}$ The next significant aspect of China's local wars is that the concept does not mean local in the sense of China's borders, but in the scope of the war's objectives and geography meaning that there is no specific location for these wars in respect to China. ${ }^{52}$ These two ideas within China's concept of operations indicate that China's future use of an expeditionary force would be a force capable of using modern technology to secure the political objectives of the Chinese leadership.

The last military strategic concept is the well-known People's War. Cordesman argues that while most think of People’s War as Mao's guerrilla warfare, they are mistaken. ${ }^{53}$ People’s War actually focuses on the population assisting the military primarily through political and logistical means, with an organized militia being the operational support. ${ }^{54}$ Using the concept of People’s War, Chinese expeditionary forces would typically use her people in support of her logistical efforts. These logistical efforts could come in the form of using civilian shipping to transport supplies and forces, or the use of ports and airfields with Chinese business ties.

With the overarching strategic military theory of warfare identified, Cordesman describes the operational concept of China's theory of warfare is campaign doctrine. The major components of campaign doctrine are similar to the concepts used in most modern militaries.

\footnotetext{
${ }^{50}$ Cordesman, 125.

${ }^{51}$ Ibid.

52 Ibid.

${ }^{53}$ Ibid., 126.

${ }^{54}$ Ibid.
} 
These concepts include integrated joint operations, information warfare, integrated firepower operations, mobility, and comprehensive support. Integrated joint operations and integrated firepower operations are the cooperation between services to augment combat power when necessary and support the overall campaign objectives. ${ }^{55}$ Information warfare aims to gain information supremacy, protect her own command and control networks, and degrade her adversaries' through such methods as cyber warfare. ${ }^{56}$ Mobility is the agile maneuvering and use of deception operations to gain local superiority and defeat the enemy. ${ }^{57}$ One major consideration of the Chinese concept of mobility is the identification of vertical envelopment by aircraft, helicopter, or parachute. ${ }^{58}$ The final concept is comprehensive support, which is the sustainment piece of her operations, most notably highlighting the use of civilians to support its logistics capabilities as discussed regarding the People’s War. ${ }^{59}$

In addition to Cordesman's report on China's military, another RAND study, China's Incomplete Military Transformation: Assessing the Weaknesses of the People's Liberation Army (PLA), discusses China's military transformation since the early 1990s and the gaps between her stated goals and military realities. ${ }^{60}$ While offering no disagreements with Cordesman's report, China's Incomplete Military Transformation captured additional details at the campaign level that

\footnotetext{
${ }^{55}$ Cordesman, 127, 134.

${ }^{56}$ Ibid., 128-129, 134.

${ }^{57}$ Ibid, 135.

${ }^{58}$ Ibid., 136.

${ }^{59}$ Ibid., 136-137.

${ }^{60}$ Chase et al., China's Incomplete Military Transformation: Assessing the Weaknesses of the People's Liberation Army (PLA) (Santa Monica, CA: RAND, National Defense Research Division, February 2015), accessed February 12, 2015, http://www.rand.org/pubs
} /research_reports/RR893.html, ix. 
are relevant to identifying China's way of expeditionary warfare. The report identified several different mission sets, relevant campaigns, and her intended campaign effects. ${ }^{61}$ While there are several different missions and campaign aspects, the ones relevant to the discussions on expeditionary warfare are periphery missions, Taiwan missions, and maritime claim missions. The periphery missions are mostly offensive with the intent of achieving or securing China's national interests in the Asia-Pacific region. ${ }^{62}$ Under periphery missions, there are two major considerations of positional offensive campaign, which involves assaulting an enemy or enemy fortified position, and an airborne campaign aimed at the depth of the enemy's territory. ${ }^{63}$ The ability to attack fortified positions successfully and conduct airborne operations against an enemy’s depth serves as dual purpose capabilities. While stated under periphery operations, modern militaries require these same tasks when conducting combat operations abroad. The next mission set is the Taiwan mission which consists of operations directed at bringing Taiwan back under the “One-China Principle.”64 However, the wider implications are that the mission’s tasks include goals of seizing and occupying an island with sub-goals of conducting a sea crossing, destroying an enemy's defenses, and securing a beachhead. ${ }^{65}$ While any other amphibious operation involves a great deal more distance, the doctrinal concepts of an operation against Taiwan are valid in conducting operations against other nations in the region. The final considerations are the maritime claim missions centered on China's efforts to secure the many

\footnotetext{
${ }^{61}$ Chase et al., 27.

${ }^{62}$ Ibid., 30.

${ }^{63}$ Ibid., 31-32.

${ }^{64}$ Ibid., 32. The "One-China Principle” is the People's Republic of China's belief that there is only one China, and Taiwan is a part of the PRC. Michal Roberge and Youkyung Lee, "China-Tawian Relations," Council on Foreign Relations, last modified August 11, 2009,

${ }^{65}$ Ibid., 33.
} accessed April 09, 2015. 
islands within the South and East China Seas. ${ }^{66}$ Within this mission set are the sea force group campaigns aimed at destroying or neutralizing an enemy navy, coral reef offensive campaigns directed at coral island reef areas such as the disputed islands, and naval coastal raid campaigns aimed at attacking enemy bases and harbors to destroy a rival's ability to project power. ${ }^{67}$ While China's mission sets are directed towards defending and supporting her national interests within her near seas, the doctrinal foundations inherent in these missions are easily expandable to allow China to conduct major combat operations and campaigns.

Returning to Cordesman’s description of China’s military and her expeditionary potential, he moves down from the campaign level to the service specific strategy. The People's Liberation Army-Navy’s (PLAN) doctrine of “near seas” or “offshore defense” calls for the PLAN to be ready to conduct operations out to the first island chain. ${ }^{68}$ While "near seas" and "defense" do not refer to offensive operations, the major consideration that three US defense treaty allies fall within or at the boundary of the first island chain make that capability a concern. The PLA-Air Force (PLAAF) operates under the supplemental doctrine of "integrated air and space operations, being prepared for simultaneous offensive and defensive operations." ${ }^{69}$ This doctrine calls for PLAAF to have the ability to not only defend Chinese territory, but also be able to conduct long-range strikes and power projection. ${ }^{70}$ Cordesman further elaborates the power projection characteristic later in his report by stating the PLAAF is supposed to be capable of

\footnotetext{
${ }^{66}$ Chase et al., 34.

${ }^{67}$ Ibid., 35.

${ }^{68}$ Cordesman, 137.

${ }^{69}$ Ibid.

${ }^{70}$ Ibid.
} 
augmenting the operational reach of the PLA. ${ }^{71}$ This augmentation could possibly be in the form of strategic lift capabilities. The final significant component of the services is the PLA's focus on pushing joint operations down from the level of corps to divisions and brigades. ${ }^{72}$ The practice of conducting joint operations at a lower level allows for the more flexible deployment of smaller forces, such as sending a brigade or division on an operation away from the larger body of a corps or army. This ability increases the range of operations along the scale of military operations to include placing an armed force ashore in a FEO type environment.

With these overarching concepts, strategies, and doctrine described, one can begin to identify a possible pattern for China’s expeditionary framework. The Chinese military will not fight as an individual service, but will rely on joint operations that take advantage of its service component firepower and advanced technology. Additionally, the sustainment of its forces will include military and civilian personnel. Finally, the joint operations, integrated fires, and advanced technology are similar to US doctrinal concepts. The Chinese expeditionary way of war will be similar to the United States and other Western nations, except in the area of civilian support. Therefore, the critical capabilities and enablers pulled from the analysis of Western doctrine and lessons learned should be relevant to China's military as well.

\section{Critical Capabilities and Enablers}

With a general Chinese way of expeditionary war discussed, the analysis of US, UK, French, and NATO doctrine and lessons learned allows the identification of those critical capabilities and enablers required for the range of expeditionary missions. Each category and their specific operations require varying degrees of these capabilities and enablers in terms of

\footnotetext{
${ }^{71}$ Ibid., 263.

${ }^{72}$ Ibid., 125.
} 
duration and numbers to provide a nation with a reasonable assurance of mission success. The capabilities of air superiority, sea control, and sustainment becomes apparent, in addition to the key enablers of strategic lift and refueling, maneuverability of forces in diverse terrain through helicopters or vehicles, and timely and adequate intelligence provided by ISR. Within crisis and limited contingency operations, NEO and PO highlight these capabilities and enablers. According to US doctrine, understanding the operational environment is a major consideration for any NEO. ${ }^{73}$ To understand an environment, a military requires ISR platforms to collect the necessary information to reduce the ambiguity forces may encounter. Australian doctrine is even more explicit in its requirement for proper intelligence support, along with highlighting sustainment considerations, and the movement of forces and evacuees by air, sea, or land. ${ }^{74}$ Additionally, Australian doctrine emphasizes that a reduced footprint may be necessary at times. ${ }^{75}$ A method of meeting this requirement is to deploy forward only those forces necessary for the immediate accomplishment of the NEO, which typically means that support and logistical personnel and assets remain outside of the affected country. This leads to a requirement for strategic lift and refueling capability to extend the reach of aircraft to get into the country, or the ability to seabase. Furthermore, a study conducted on the US NEO from Mogadishu, Somalia in 1991 echoes the Australian requirements of sustainment and movement of forces. While the operation was successful, the study identified strategic airlift and refueling capability, helicopters for increased maneuver capability, and fire support for both evacuees and sustainment helicopters as potential shortfalls. ${ }^{76}$ This review provides the requirements of appropriate intelligence, sustainment

${ }^{73}$ JP 3-68, I-4 - 5.

${ }^{74}$ Commonwealth of Australia, Australian Defence Doctrine Publication 3.10, Noncombatant Evacuation Operations (Canberra, Australia: Defence Publishing Service, 2011), accessed October 30, 2014, http://www.defence.gov.au/adfwc/Documents/DoctrineLibrary/ ADDP/ADDP_3_10_Noncombatant_Evac_Ops.pdf, 4-19 - 4-23.

${ }^{75}$ Ibid., 4-12.

${ }^{76}$ Siegel, 11-12. 
through strategic lift and refueling and seabasing, and maneuverability around the area with the appropriate protection, typically in the form of helicopters.

The next operation within the crisis and limited contingency operations category is PO. Two RAND studies analyzed and identified a range of operations within PO based on levels of “intrusiveness” ranging from observation, interposition, transition, security for humanitarian aid, peace enforcement, and highlighted several mission requirements. ${ }^{77}$ As one progressed along the scale of intrusiveness, the range of capabilities required to be successful at each level increased. These capabilities start with strategic lift and intelligence collection, moving to emplacing and sustaining ground forces, and finally to conducting a forced entry (not to be confused with the same scale and requirements of FEO described previously), and joint operations. ${ }^{78}$ These requirements at the far end of complexity and risk come very close to major combat operations and can easily spill over into that realm. This is why the requirement to conduct PO must include a limited capability to conduct operations designed to land and sustain limited forces in a potentially hostile environment. In addition to the RAND Study, British doctrine highlights the need for strategic airlift, ability to move in and around the affected area, logistics efforts to bring

in relief items and support personnel, and ISR assets to inform disaster response and military personnel of threats and the environment. ${ }^{79}$

${ }^{77}$ Bruce R. Pirnie and William E. Simons, Soldiers for Peace: An Operational Typology, Guidelines for U.S. Involvement in Peace Operations (Santa Monica, CA: RAND, National Defense Research Institute, 1996), accessed November 4, 2014, http://www.rand.org/pubs/ monograph_reports/MR582.html, 38-39. Additionally, Bruce R. Pirnie and William E. Simons, Soldiers for Peace: Critical Operational Issues, Guidelines for U.S. Involvement in Peace Operations (Santa Monica, CA: RAND, National Defense Research Institute, 1996), accessed November 4, 2014, http://www.rand.org/pubs/monograph_reports/MR583.html, 25.

${ }^{78}$ Soldiers for Peace: Critical Operaitonal Issues, 25.

${ }^{79}$ Chiefs of Staff, Joint Doctrine Publication 3-52, Disaster Relief Operations, 3-13 3-14. 
In addition to the capabilities identified under NEO, PO adds the requirements for limited forced entry and joint operations. Forced entry refers to the ability to project forces ashore, but the assumption is that the opposing forces, while potentially hostile, are not able to oppose a landing at the same level of those expected in a FEO. However, a forced entry requires the ability to conduct joint operations. Joint operations, as defined by US doctrine, involves the employment of more than one service, but goes further by highlighting the common operating precepts of integration of capabilities to support each service. ${ }^{80}$ An example of this can be the fire support of a landing force by naval ships and air force strike aircraft. The key point is that the whole of the force, land, sea, and air components, must be able to complement each other and work towards the success of putting forces ashore.

While the previous section described FEO through the lens of PO, this section views FEO within major combat operations and campaigns category. US doctrine lists several principles that are required to establish favorable conditions: achieve surprise, control of the air, control of space, electromagnetic spectrum management, operations in the information environment, sea control, isolate the lodgment, gain and maintain access, neutralize enemy forces within the lodgment, expand the lodgment, manage the impact of environmental factors, and integrate supporting operations. ${ }^{81}$ For the purpose of identifying those key capabilities and enablers for FEO, the focus of analysis will be on control of the air, sea control, expanding the lodgment due to these requiring capabilities and enablers that are in low supply and typically unclassified.

US joint doctrine describes control of the air as air superiority, which provides the commander freedom of action, protection from enemy air and missile threats, and denies the

\footnotetext{
${ }^{80}$ JP 3-0, I-1, I-3.

${ }^{81}$ JP 3-18, I-5.
} 
enemy the ability to target friendly forces. ${ }^{82}$ US doctrine goes on to explain while there may be different levels of air superiority, the level recommended is based on what a commander requires to have sufficient control of the air to attack the enemy without major opposition, while denying the enemy the same ability. ${ }^{83}$ NATO Allied Joint Publication 3.3.3, Allied Joint Doctrine for the Conduct of Operations further lists several types of operations that fall into the air superiority capability and directly link to the enablers and requirements mentioned earlier: counter-air, air power contributions to maritime operations, reconnaissance and surveillance, electronic warfare, air transport, and air-to-air refueling. ${ }^{84}$ The Combined Joint Expeditionary Force (CJEF) User Guide echoes the US and NATO doctrine by emphasizing that air assets will be sufficient to fill the air role that will enable complex operations. ${ }^{85}$ The descriptions of air superiority and relevant operations and ideas directly correlate to enablers of strategic lift and refueling, maneuverability around the battlefield for operations and sustainment, and ISR support.

The principle of sea control is captured extremely well by the Combined Joint Expeditionary Force (CJEF) User Guide when it states sea control is the "principal requirement for the maritime element of the CJEF and the essential prerequisite for the projection of military

82 JP 3-01, I-1.

${ }^{83}$ John Warden, The Air Campaign: Planning for Combat (Fort Lesley J. McNair, Washington, DC: National Defense University Press, 1988), accessed December 3, 2014, http://babel.hathitrust.org/cgi/pt?id=uiug.30112006718891;view=1up;seq=4, 13.

${ }^{84}$ North Atlantic Treaty Organization, Allied Joint Publication 3.3.3, Allied Joint Doctrine for Air-Maritime Coordination, ed. A, ver. 1 (Brussels, Belgium: NATO Standardization Office, December 2014), accessed February 5, 2015, http://nso.nato.int/ nso/zPublic/ap/AJP-3.3.3\%20EDA\%20V1\%20E.pdf, 3-2 - 3-3..

${ }^{85}$ The CJEF is a joint UK and French force designed to respond to a wide range of operations to include high intensity operations. United Kingdom Ministry of Defence and Republic of France French Joint Staff, Combined Joint Expeditionary (CJEF) User Guide (Shrivenham, England and Paris, France: Development, Concepts and Doctrine Centre and Centre Interarmées de Concepts, de Doctrine et d'Expérimentations, 2012), accessed February 5, 2015, http://www.cicde.defense.gouv.fr/IMG/pdf/20121218_np_cicde_dcdc_cjef-user-guide.pdf, 4-6 4-7, iii. 
power, even when an operation is inland." ${ }^{86}$ NATO doctrine defines sea control as the condition that exists when one has freedom of action within an area of the sea for a period of time." ${ }^{87}$ US doctrine adds only an emphasis on the destruction of enemy naval forces to assist in obtaining sea control. ${ }^{88}$ The condition of sea control allows friendly forces to maneuver from sea to shore, provide adequate ISR support, and provide uninterrupted sustainment to forces ashore.

While the final principle mentioned was expand the lodgment, a critical aspect of that principle that makes FEO more difficult is the sustainment piece of continuously pushing troops and materiel into the theater and ashore. ${ }^{89}$ The lack of sustainment to forces ashore drastically reduces a nation's effects in terms of scope and scale. NATO emphasizes the importance of preventing this lack of sustainment by succinctly describing sustainment as the foundation of conducting operations..$^{90}$ The scope of sustainment ranges from receiving, deploying, and replenishing forces, as well as, establishing bases and lines of communication. ${ }^{91}$ Within sustainment, seabasing is an important category that vastly increases distance and time over which a military force can conduct operations. US joint doctrine describes seabasing as a way of deploying forces into a theater, conducting operations, and redeploying without the use of land

${ }^{86}$ Combined Joint Expeditionary (CJEF) User Guide, 4-5.

${ }^{87}$ North Atlantic Treaty Organization, AAP-06, NATO Glossary For Terms and Definitions, 2014th ed. (Brussels, Belgium: NATO Standardization Agency, 2014), accessed February 5, 2015, http://nso.nato.int/nso/zPublic/ap/aap6/AAP-6.pdf, 2-S-3.

${ }^{88}$ Joint Chiefs of Staff, Joint Publication 3-32, Command and Control for Joint Maritime Operations (Washington, DC: Government Printing Office, August 7, 2013), accessed December 8, 2014, http://www.dtic.mil/doctrine/new_pubs/jp3_32.pdf, I-3 - I-4.

89 JP 3-18, I-5.

${ }^{90}$ AJP-3, 1-22.

${ }^{91}$ Ibid. 
bases. ${ }^{92}$ Seabasing enables a military force to operate with fewer political restrictions due to its location in international waters, reduces the reliance on land bases, expands access options, and extends the time of the force on station. ${ }^{93}$ The ability to establish a sea base in international waters and reduce the reliance on land bases allows the military force to maintain a small footprint for non-combat operations and mitigate the risks of an enemy's $\mathrm{A} 2 / \mathrm{AD}$ in combat operations by staying outside of those ranges. ${ }^{94}$ Moreover, seabasing provides a nation more options on when and where to conduct operations, and offers additional protection to those forces involved in the operation. By not relying on a port or airfield, a force can prepare outside of the $\mathrm{A} 2 / \mathrm{AD}$ threat, and then conduct operations against the enemy forces ashore due to multiple points and methods of entry. ${ }^{95} \mathrm{~A}$ final important benefit of seabasing is that it allows the conduct of operations for extended periods due to costs. Without this ability to sea base, a state's options of sustaining its forces are limited to air or land. Both of these methods of supply are costly and inefficient, thus placing a greater strain on a state's capabilities. This aspect of cost is so significant that even the US Army modified its concept of deploying and sustaining forces via aircraft due to the high cost of the number of aircraft required to move and sustain its forces. ${ }^{96}$

The UK's FEO and follow-on operations to recapture the Falklands in 1982 provides an example of seabasing and shows the amount and type of forces, equipment, and assets required to

92 Joint Chiefs of Staff, Joint Publication 3-02, Amphibious Operations (Washington, DC: Government Printing Office, July 18, 2014), accessed December 1, 2014, http://www.dtic.mil/ doctrine/new_pubs/jp3_02.pdf, III-38.

${ }^{93}$ Button et al., 6-7.

${ }^{94}$ Ibid., 6-7.

${ }^{95}$ Chairman Joint Chiefs of Staff, Joint Operational Access Concept (JOAC), 20.

${ }^{96}$ Button et al., 12. 
achieve the goal of securing a lodgment. ${ }^{97}$ During this two-week operation, the British used fiftyone warships, twenty-one fleet auxiliaries, fifty-four merchant vessels, and thirteen air squadrons, and over ten thousand marines and soldiers. ${ }^{98}$ While the length of the operation may seem limited, the massive amounts of vessels, aircraft, marines, and soldiers, not to mention the vast quantities of necessary supplies, highlights the large scale of manpower and resources that are involved in a FEO. While the British did receive support from other nations during this operation, the ability to conduct seabasing allowed them to extend a nation's ability of force projection greatly.

Although the focus of force projection through expeditionary means has centered on some type of amphibious landing requirement, the capabilities of air superiority, sea control, and sustainment remain valid in all expeditionary operations. Air superiority and sustainment are typically major priorities in land, air, and sea warfare, while the condition of sea control seems less of a requirement in a major land campaign between two land forces. However, as British naval theorist Sir Julian Corbett highlights, attacking the enemy's trade and financial resources at sea are vital to military success. ${ }^{99}$ With his theory on attacking sea trade being widely known and accepted, the additional fact that over ninety percent of international trade travels by sea emphasizes the importance of sea control. ${ }^{100}$ Additionally, as the largest importer of petroleum in the world, most of this coming by sea, China is very sensitive to the significance of sea control in

${ }^{97}$ Joseph H. Alexander, Sea Soldiers in the Cold War: Amphibious Warfare, 1945-1991 (Annapolis, MD: Naval Institute Press, 1995), 112.

${ }^{98}$ Ibid., 115-116.

${ }^{99}$ Julian Stafford Corbett, Some Principles of Maritime Strategy, The Project Gutenberg ebook, 2005, accessed February 8, 2015, www.gutenberg.org/ebooks/15076, 99-100.

${ }^{100}$ Sonia Koesnikov-Jessop, "Shippers Examine Advantages of Fuel Change," The New York Times, January 19, 2011, accessed February 8, 2015, www.nytimes.com/2011/01/20/ business/global/20iht-rbogship.html?pagewanted=all\&_r=0. 
major operations and campaigns. ${ }^{101}$ Air superiority, sea control, and sustainment to forces ashore may have varying roles and scale within the framework of expeditionary operations, but all three are vital considerations for analyzing China’s expeditionary capabilities.

The review and analysis of these categories of military operations identifies several critical capabilities and enablers. The key enablers were strategic lift, maneuverability of forces in diverse terrain typically by helicopters, timely and adequate ISR support, and deployment, conduct of operations, and redeployment of forces by land and sea. Each of these enablers and capabilities fits into the key concepts highlighted under the principles of FEO: air superiority, sea control, and sustainment of forces in the area of operations.

\section{Evaluation Criteria}

The next step to determining China's force projection capability is to analyze its true capabilities with an evaluation criterion that is not limited to only equipment or manpower. While these factors are important, multiple factors are required to provide security experts the proper criteria to assess the capabilities needed to accomplish a wide range of military operations. To capture all of the required evaluation criteria, this paper will use the concept of RMA and several aspects of DOTMLPF to assess force projection capability and identify any potential gaps that could prevent or inhibit successful operations.

An RMA is the paradigm shift that occurs when a new concept or technology changes the way militaries conduct operations, because this change makes the fundamental abilities of some set of military capabilities irrelevant or obsolete. ${ }^{102}$ While the term RMA is a relatively

${ }^{101}$ Candace Dunn, "China Is Now the World's Largest Net Importer of Petroleum and Other Liquid Fuels,” March 24, 2014, US Energy Information Administration, accessed February 8, 2015, www.eia.gov/todayinenergy/detail.cfm?id=15531.

102 Richard O. Hundley, Past Revolutions, Future Transformations: What Can the History of Revolutions in Military Affairs Tell Us about Transforming the U.S. Military? (Santa Monica, CA: RAND, 1999), accessed October 18, 2014, http://www.rand.org/content/dam/ rand/pubs/monograph_reports/2007/MR1029.pdf, xv. 
contemporary term, history provides numerous examples of RMAs. One example is the use of the telegraph in the Austro-Prussian War in 1866. Although the Union and Confederate forces both used the telegraph in the American Civil War, the way in which the Prussians utilized the telegraph created the paradigm shift. The inclusion of the telegraph in more tactical matters to assist in the mobilization and deployment of armies, and the coordination and control of armies over great distances challenged the fundamental abilities of the Austrians to react accordingly, providing the Prussians with an advantage. ${ }^{103}$ While this new technology may provide the possibility of an advantage, it does not guarantee a successful RMA. A necessary structure and expertise is required to allow the full exploitation of this new technology. Broadly, the process of RMA requires a nation-state to possess the necessary technologies that can counter a potential adversary's core competency. ${ }^{104}$ Once the nation-state possesses this technology, it must develop or adapt an organization to integrate this breakthrough to make it viable. ${ }^{105}$ Finally, this organization must be able to experiment, test, and practice with this new technology. ${ }^{106}$ The technology factor is the necessary component to overcome a key adversary capability. The organization must be able to exploit the technology, and the doctrine must provide a general operating concept for the technological breakthrough. ${ }^{107}$ A modern day example could be the technological breatkthrough of the B-2 Spirit Stealth bomber. The breakthrough came in the form of the stealth technology allowed the B-2 to penetrate the most advanced air defense systems, and

${ }^{103}$ Martin Van Creveld, Command in War (Cambridge, MA: Harvard University Press, 1985), 145.

\footnotetext{
${ }^{104}$ Hundley, 59.

105 Ibid.

${ }^{106}$ Ibid.

${ }^{107}$ Hundley, 15.
} 
rendered those adversary air defense assets useless. ${ }^{108}$ However, the United States had to create and incorporate the B-2 into units and develop a general concept of how the US Air Force would employ the aircraft.

In addition to RMA, DOTMLPF is another useful tool that can help identify gaps in a state's force projection capability. DOTMLPF is the US Joint Staff's construct to ensure changes to anything within DOTMLPF is not disruptive and is fully integrated into the military apparatus. ${ }^{109}$ As RMA already discusses technology, organization, and doctrine, the focus will be on DOTMLPF's remaining factors of training, materiel, personnel, and facilities to address other identifiable gaps. Additionally, this paper will not analyze leadership and education due to limited amount of information available and this framework aimed at gauging current and future states independent of specific personalities. The first factor of DOTMLPF that will be explored, training, includes all the time and events spent learning a tactical or operational task required to complete the mission. ${ }^{110}$ Materiel consists of all the necessary equipment that military forces require to complete the mission. ${ }^{111}$ Materiel should not be confused with technology, which focuses on new concepts or capabilities that provide one nation a specific advantage over another. Personnel are simply the appropriate number of adequately skilled people that can accomplish the

108 "B-2 Spirit Stealth Bomber - Centerpiece of Long Range Strike”, Northrop Grumman Corporation, accessed April 09, 2015, http://www.northropgrumman.com/capabilities /b2spiritbomber / pages/default.aspx.

${ }^{109}$ Joint Chiefs of Staff, Chairman of the Joint Chiefs of Staff Instruction 3010.02D, Guidance for Development and Implementation of Joint Concepts (Washington, DC: Government Printing Office, November 22, 2013), accessed October 18, 2014, http://www.dtic.mil/cjcs_ directives/cdata/unlimit/3010_02.pdf, A-3. The Joint Chiefs of Staff's DOTMLPF actually includes policy, however, policy is outside the scope of this paper due to the lack of transparency of the Chinese government.

110 Ibid., A-3 - A-4.

${ }^{111}$ Guidance for Development and Implementation of Joint Concepts, A-4. 
necessary task. ${ }^{112}$ The final factor consists of the facilities that are necessary to mobilize, move, and sustain the forces needed to complete the mission. ${ }^{113}$ These factors, combined with those from RMA, provide the analytic framework (see table 1) to assess China's capabilities and identify those gaps that prevent them from conducting the full range of military operations. By using RMA and DOTMLPF, one can analyze the capabilities of air superiority, sea control, and sustaining the force along with their key enablers. This analysis provides a yes or no to the country possessing the necessary enablers or a substitute that allows them to have the necessary capability and identifies the gap if one is present.

Table 1. RMA/DOTMLPF Template

\begin{tabular}{|c|c|c|c|c|}
\hline Factor & $\begin{array}{c}\text { Does the nation- } \\
\text { state possess the } \\
\text { necessary } \\
\text { capability? }\end{array}$ & $\begin{array}{l}\text { What do they } \\
\text { use to meet this } \\
\text { gap? }\end{array}$ & $\begin{array}{c}\text { What is the } \\
\text { identifiable } \\
\text { gap? }\end{array}$ & $\begin{array}{c}\text { Has the } \\
\text { gap been } \\
\text { addressed? }\end{array}$ \\
\hline \multicolumn{5}{|c|}{ RMA } \\
\hline \multicolumn{5}{|l|}{ Technology } \\
\hline \multicolumn{5}{|l|}{ Doctrine } \\
\hline \multicolumn{5}{|l|}{ Organization } \\
\hline \multicolumn{5}{|c|}{ DOTMLPF } \\
\hline \multicolumn{5}{|l|}{ Training } \\
\hline \multicolumn{5}{|l|}{ Materiel } \\
\hline \multicolumn{5}{|l|}{ Personnel } \\
\hline Facilities & & & & \\
\hline
\end{tabular}

Source: Created by author based on information gathered during research.

Using the table above, analysis of two expeditionary cases identifies those key enablers that allow or prevent a state from achieving air superiority, sea control, or sustaining the force.

\footnotetext{
${ }^{112}$ Ibid., A-5.

${ }^{113}$ Ibid.
} 
Three considerations weighed heavily when deciding what type of case studies were needed: (1) occur in the post-Cold War era; (2) involve moving forces over five hundred miles; and (3) involve combat operations. The temporal requirement places the case studies in a world where super-power geopolitics put most events in a Soviet Union or US backed camp. Additionally, while analyzing historical events such as Japan's invasion of the Philippines in World War II would show the importance of the key capabilities required to conduct expeditionary operations, the ability to pull modern enablers out of those events would be useless. The requirement to have a nation move its forces a minimum of five hundred miles places a larger strain on sustainment forces, especially strategic lift. Additionally, five hundred miles is the distance Chinese sustainment would have to operate to ensure her forces could operate past the First Island Chain. Finally, the purpose of including case studies that involve combat operations moves towards a major consideration of expeditionary operations, force projection. Sending forces outside a nation's borders without conducting combat operations does not put stress on the government's ability to ensure those forces have the required capabilities to conduct their operation successfully. These considerations led to choosing the 2000 British intervention in Sierra Leone and the 2013 French operations in Mali. While both operations received some help from the United States and other nations, the conduct of the operations themselves provide a good view of what contemporary enablers are required to ensure air superiority, sea control, and continuous sustainment.

\section{Case Studies}

The 2000 British Intervention in Sierra Leone 
The British intervention in Sierra Leone provides a contemporary case study of a powerful nation intervening far from its near seas with substantial military force in a situation that falls within US joint doctrine’s category of crisis response and limited contingency operations. The operation, named Operation Palliser, began as a NEO, and then progressed into a Peace Enforcement Operation. ${ }^{114}$ In addition to Operation Palliser, the British followed-up with a hostage rescue, Operation Barras, within Sierra Leone. These operations provide good examples of the requirements needed to send forces far from their home territory to conduct complex peace and combat actions.

Since 1967, only six years after receiving independence from Britain, Sierra Leone’s government suffered from several authoritarian rulers and multiple coup d'états that weakened the legitimacy of the government and provided the opening for civil war with the Revolutionary United Front (RUF) in 1991. ${ }^{115}$ Although the RUF had been building an insurgency in the late 1990s and early in 1991, her offensive (supported by Charles Taylor’s Liberian rebel forces) launched in late March and early April 1991 into eastern and southern Sierra Leone marked the beginning of the Sierra Leone Civil War. ${ }^{116}$ This civil war raged unabated through multiple involvements of external actors such as foreign private security firms, the Economic Community of West African States and its military force, the Economic Community of Western African States Military Observer Group, and finally, UN and British intervention. ${ }^{117}$

114 JP 3-01, V-23.

${ }^{115}$ Abass Bundu, Democracy by Force?: A Study of International Military Intervention in the Civil War in Sierra Leone from 1991-2000 (Parkland, FL: Universal Publishers, 2001), 41-54.

${ }^{116}$ Larry J. Woods, Military Interventions in Sierra Leone: Lessons from a Failed State, The Long War Series (Fort Leavenworth, KS: Combat Studies Institute Press, US Army Combined Arms Center, 2008), 15-17.

${ }^{117}$ Ibid., 28, 41-42. 
Following brutal fighting between the RUF and the Economic Community of West African States Military Observer Group, the Sierra Leone government and the RUF were able to agree to the Lomé Peace Agreement in July 1999. ${ }^{118}$ To assist the enforcement of the agreements terms, the United Nations Security Council passed Resolution 1270 mandating the United Nations Assistance Mission in Sierra Leone (UNAMSIL) to participate in peacekeeping operations to ensure security and freedom of movement, assist with disarmament and reintegration of RUF fighters, monitor the ceasefire, and provide humanitarian support. ${ }^{119}$ From early on, the UNAMSIL mission suffered many logistics and command and control problems, and once the Economic Community of Western African States Military Observer Group forces had withdrawn, suffered major losses to the RUF and the capture of hundreds of UNAMSIL peacekeepers. ${ }^{120}$ Because of these significant losses and hostage taking, the UN SecretaryGeneral called for assistance from the member nations to shore up UNAMSIL on May 4, 2000. ${ }^{121}$ The British responded with the deployment of an Operational Liaison and Reconnaissance Team

that arrived in Sierra Leone on May 6, officially beginning Operation Palliser. ${ }^{122}$

${ }^{118}$ Ibid., 45-48.

${ }^{119}$ United Nations Security Council, "Sierra Leone - UNAMSIL - Mandate,” October 22, 1999, United Nations, accessed November 18, 2014, http://www.un.org/en/peacekeeping/ missions/past/unamsil/mandate.html.

${ }^{120}$ Woods, 55-60. Additional information was pulled from David Harris, Civil War and Democracy in West Africa: Conflict Resolution, Elections and Justice in Sierra Leone and Liberia (New York: I .B. Tauris, 2012), accessed November 10, 2014, http://search.ebscohost. com/login.aspx?direct=true\&scope=site \&db=nlebk\&db=nlabk\&AN=433746, 76-77.

${ }^{121}$ Woods, 60.

${ }^{122}$ Andrew M. Dorman, Blair's Successful War: British Military Intervention in Sierra Leone, Military Strategy and Operational Srt (Farnham, England: Ashgate, 2009), 76. 
The Operational Liaison and Reconnaissance Team's initial role was the planning of a NEO of British citizens and citizens of other designated countries with the subsequent objective of assisting UNAMSIL. ${ }^{123}$ On May 7, British Special Forces squadron and parachute regiment units moved by air from a French air base in Dakar, Senegal to Lungi Airport to seize the key entry/exit point to facilitate the NEO and follow-on operations. ${ }^{124}$ While the ground forces were moving into place, the HMS Illustrious, a British aircraft carrier, and its battle group began moving towards Sierra Leone to provide offensive air support. ${ }^{125}$ Additionally, the British Royal Marine Amphibious Ready Group began movements from Marseille, France to provide additional ground forces. On May 8, following a violent protest in Freetown, the British began executing her NEO operation and completed the evacuation by May 9 with the help of seventeen transport aircraft. ${ }^{126}$ Shortly after the successful completion of the NEO, British forces began the task of actively supporting and assisting the UNAMSIL forces. ${ }^{127}$ By May 14, the Amphibious Ready Group and the HMS Illustrious arrived replacing the parachute regiment. ${ }^{128}$ Four days later,

additional shipping and the HMS Ocean, a helicopter carrier, arrived in the littorals of Sierra Leone. ${ }^{129}$ Additionally, the British deployed its fixed wing intelligence-gathering platform and

${ }^{123}$ Ibid., 78-79.

${ }^{124}$ Ibid., 79.

${ }^{125}$ Ibid., 80. HMS Illustrious primarily launched vertical/short take-off Harriers.

${ }^{126}$ Ibid., 75, 80-82.

${ }^{127}$ Dorman, 90-91.

${ }^{128}$ Ibid, 92.

${ }^{129}$ Richard Connaughton, "The Mechanics and Nature of British Interventions into Sierra Leone (2000) and Afghanistan (2001-2002),” Civil Wars 5, no. 2 (March 2002): 85. 
tanker support to assist in the operations. ${ }^{130}$ From the completion of the NEO to the formal conclusion of Operation Palliser on June 15, British forces primarily conducted peace operations to include advising and assisting the Sierra Leone Army and UNAMSIL forces; however, the British forces did engage and defeat RUF forces. ${ }^{131}$ With the arrival of more UNAMSIL forces and the successful operations that had pushed the RUF to the fringes of Sierra Leone, British forces (outside those assigned as UNAMSIL forces) left on June $15{ }^{132}$

While the regular British military forces may have thought her time in Sierra Leone had ended, further actions against UNAMSIL by militia brought them back. The West Side Boys (WSB), initially a Sierra Leone backed militia against the RUF, broke away from the government and established a base of operations to launch attacks on the local community and government forces. ${ }^{133}$ The WSB became a British priority on August 25, 2000 when they kidnapped eleven British Soldiers serving in a peacekeeping role. ${ }^{134}$ Following initially successful negotiations that led to the release of five British Soldiers, on September 10, the British Government decided to launch an assault against the WSB to free the remaining captives. The operation consisted of British Special Forces, launched from the HMS Ocean, providing intelligence and hostage rescue, while a battalion of British parachute infantrymen were to defeat other WSB forces and secure a landing zone to extract the hostages. ${ }^{135}$ In addition to these ground forces, they utilized two attack helicopters to provide air support, while three chinooks operating from the HMS Ocean offloaded

\footnotetext{
${ }^{130}$ Dorman, 93.

${ }^{131}$ Woods, 62-64.

132 Ibid., 64.

${ }^{133}$ Dorman, 104-105.

${ }^{134}$ Ibid., 105.

${ }^{135}$ Woods, 68-69.
} 
troops and retrieved the hostages and wounded. ${ }^{136}$ This operation resulted in the rescue of the British hostages, the capture of Sierra Leoneans, twenty-five casualties, and the capture of fifteen WSB members at the cost of one British casualty and eleven injured. ${ }^{137}$

Table 2. RMA/DOTMLPF for the UK

\begin{tabular}{|c|c|c|c|c|}
\hline Factor & $\begin{array}{l}\text { Does the nation- } \\
\text { state possess the } \\
\text { necessary } \\
\text { capability? }\end{array}$ & $\begin{array}{l}\text { What do they } \\
\text { use to meet this } \\
\text { gap? }\end{array}$ & $\begin{array}{c}\text { What is the } \\
\text { identifiable } \\
\text { gap? }\end{array}$ & $\begin{array}{c}\text { Has the gap been } \\
\text { addressed? }\end{array}$ \\
\hline \multicolumn{5}{|c|}{ RMA } \\
\hline Technology & Yes & N/A & N/A & N/A \\
\hline Doctrine & Yes & N/A & N/A & N/A \\
\hline Organization & Yes & N/A & N/A & N/A \\
\hline \multicolumn{5}{|c|}{ DOTMLPF } \\
\hline Training & Yes & N/A & N/A & N/A \\
\hline Materiel & $\begin{array}{l}\text { No, ability to move } \\
\text { helicopters long } \\
\text { distance or launch } \\
\text { more helicopters } \\
\text { from sea }\end{array}$ & $\begin{array}{l}\text { Flew } \\
\text { helicopters } \\
\text { there over long } \\
\text { routes and use } \\
\text { limited } \\
\text { capability from } \\
\text { HMS Ocean }\end{array}$ & $\begin{array}{l}\text { Fixed wing- } \\
\text { aircraft or } \\
\text { additional } \\
\text { amphibious } \\
\text { assault ships } \\
\text { to deploy } \\
\text { helicopters }\end{array}$ & $\begin{array}{l}\text { Yes, Britain has } \\
\text { since purchased } \\
\text { aircraft to transport } \\
\text { her helicopters }{ }^{138}\end{array}$ \\
\hline Personnel & Yes & Yes & $\mathrm{N} / \mathrm{A}$ & N/A \\
\hline Facilities & No & $\begin{array}{l}\text { French Air } \\
\text { Base }\end{array}$ & $\mathrm{N} / \mathrm{A}$ & N/A \\
\hline
\end{tabular}

Source: Created by author based on information gathered during research

While Operations Palliser and Barras were limited in time and scope, they offer a clear view of some of the capabilities needed to conduct limited crisis and contingency operations successfully. The operations involved moving hundreds of men, resources, and equipment

$$
\begin{aligned}
& { }^{136} \text { Ibid., 69-70. } \\
& { }^{137} \text { Ibid., } 71 . \\
& { }^{138} \text { Dorman, } 75 .
\end{aligned}
$$


thousands of miles to conduct a range of operations that culminated in actual combat operations. The technology involved for these operations is common among modern militaries operating against technologically inferior belligerents such as the RUF and WSB. These operations required the creation of a joint task force to coordinate and execute operations with units from the British Army, Royal Navy, Royal Air Force, and special forces. The creation of this organization was not a new concept as British doctrine and the actions relayed above show the close coordination and execution needed to accomplish these two operations. ${ }^{139}$ For both operations, British forces went through pre-deployment training, even at the expense of ending other training opportunities. ${ }^{140}$ However, the British had difficulties due to lack of sufficient materiel. Operations Palliser and Operation Barras required attack and support helicopters to be successful, yet the British did not possess the necessary cargo aircraft to transport their helicopters. ${ }^{141}$ Instead, they had to fly some of their helicopters from England to Dakar for staging. ${ }^{142}$ By flying these helicopters instead of having them transported, the British placed a great strain on the equipment and flight crews, while adding travel time that appropriate transport aircraft could have negated. While the British may not have possessed the necessary transport aircraft for all of its helicopters, the HMS Ocean was able to provide some lift capacity. The Chinooks launched from the HMS Ocean were vital to the success of the operation by moving troops from the ship to their designated locations,

${ }^{139}$ While the origins of British joint doctrine are unclear, the execution and familiarity shown during Operations Pallisar and Barras indicates joint operations were a common occurrence. For additional information on British Joint Operations, see Joint Doctrine Publication 3-52.

${ }^{140}$ Dorman highlights the 42 Commando and the HMS Illustrious Carrier Group were conducting exercises when Operation Palliser began its planning phase. Dorman, 72, 74.

$$
\begin{aligned}
& { }^{141} \text { Dorman, } 75 . \\
& { }^{142} \text { Ibid. }
\end{aligned}
$$


providing fire support, and removing forces and casualties at the end. ${ }^{143}$ As can be seen from the outcome, the personnel involved in both operations were sufficient to complete their assigned tasks. The last factor is the British lack of necessary facilities. The British did not have a staging area close enough to Sierra Leone to safely and efficiently receive and deploy their forces into Sierra Leone. The problem was resolved through discussions with the governments of Senegal and France. ${ }^{144}$ Nevertheless, the lack of basing could have been very problematic and potentially hazardous to the success of the mission if the Senegal and French governments had not allowed them to use the French air base for both operations. Even with the lack of helicopter transport aircraft or proper forward basing, the British were able to move army, navy, and air force units over three thousand miles to successfully conduct operations with little to no planning. This lack of proper lift and basing are problematic, but the British were able to offset these weaknesses through their diplomatic efforts and the exemplary display of planning, coordination, and execution of their forces.

The 2013 French Intervention in Mali

On January 11, 2013, France, at the request of the Malian government, began military operations aimed at stabilizing Mali. ${ }^{145}$ While the operation lasted well over a year until August 1, 2014, consisting of several different types of military operations, to include counterterrorism

${ }^{143}$ United Kingdom Royal Air Force, A Short History of the Royal Air Force, UK Crown, accessed March 7, 2015, http://www.raf.mod.uk/rafcms/mediafiles/F21F8E7A_BD8A_55BA_ 43FA63F04FC5D6B4.pdf, 308.

${ }^{144}$ Dorman, 75.

${ }^{145}$ French Embassy in New Delhi, “Operation SERVAL in Mali - Weekly Update: Launch of Operation SERVAL,” January 18, 2013, Ministere des Affaires Etrangeres Et Du Developpment International, accessed November 26, 2014, www.ambafrance-in.org/IMG/ pdf/Operation_Serval_in_Mali_-_Weekly_Update_1_-_18_Jan_2013.pdf?8334/ 61135643f9105e86371821586e5c020d99111329, 1. 
and peace operations, the primary focus of this case study will be the first few months of the operation that involved rapid deployment and combat operations. ${ }^{146}$ During this time, France mobilized her forces conducting military and advisory roles in Senegal, Djibouti, Chad, Côte d’Ivoire, Burkina Faso, and Gabon to deploying thousands of ground, air, and even naval assets into the region within a very short time to Mali. ${ }^{147}$

While the crisis in Mali had been building for some time due to Malian government corruption, ineptitude, and a low-level insurgency in Northern Mali, the situation turned for the worse due to a military coup in March 2012 that provided a large power vacuum in the region. ${ }^{148}$ Into that vacuum stepped terrorist organizations, Ansar Dine, the Movement for Unity and Jihad in West Africa, Al-Qaida in the Islamic Maghreb, and portions of the ethnic Tuareg population. ${ }^{149}$ These groups combined forces, moved quickly south and west from the contested Northern Mali, and captured the last government-controlled city of Konna (approximately 420 miles from the Mali capitol of Bamako). ${ }^{150}$

${ }^{146}$ Maxime H.A. Larive, “Welcome to France’s New War on Terror in Africa: Operation Barkhane,” August 7, 2014, The National Interest, accessed November 26, 2014, http://nationalinterest.org/feature/welcome-frances-new-war-terror-africa-operation-barkhane11029. Operation Barkhane is the continuation of counterterrorism operations that were conducted under Operation Serval, but with an expanded area of operations that includes much of the African Sahel.

147 John C.K. Daly, “Counterterrorism or Neo-Colonialism? The French Army in Africa,” Terrorism Monitor 12, no.5 (March 06, 2014), accessed April 09, 2015, http://www.jamestown.org/regions/africa/single/?tx_ttnews\%5Btt_news\%5D=42051\&tx_ttnews \%5BbackPid\%5D=55\&cHash=8e372fe5ecd8a63b4cfccecb1544d46e\#.VScWh_nF9Ok

${ }^{148}$ Alex Arieff, Congressional Research Service Report for Congress R2664, Crisis in Mali (Washington, DC: Library of Congress, January 14, 2013), accessed November 26, 2014, www.fpc.state.gov/documents/organization/203726.pdf, 1.

${ }^{149}$ United Nations Security Council, Report of the Secretary-General on the Situation in Mali: December 20, 2013 - March 26, 2014, United Nations, accessed November 26, 2014, www.un.org/en/ga/search/view_doc.asp?symbol=S/2013/189, 1.

${ }^{150}$ Ibid. 
These developments led to France deploying forces into Mali to stop the terrorist organizations, secure Mali, and assist Mali in recovering its territorial integrity. ${ }^{151}$ Within hours of French President François Hollande announcing the start of Operation Serval, French Special Operations Forces and attack aviation began attacking terrorist formations. ${ }^{152}$ Following these initial Special Operations Forces and attack aviation interdictions, France began deploying conventional forces into Mali from forward deployed locations around the region with the first arriving on January 11. ${ }^{153}$ The first conventional forces to arrive in Mali deployed with limited supplies to facilitate a quicker arrival. ${ }^{154}$ The forces consisted of a mixture of infantry, armor, and artillery. ${ }^{155}$ By the next day, French fighter aircraft began striking enemy targets, while additional conventional forces flowed into Mali. ${ }^{156}$ By January 18, the French had approximately 2,700 troops committed to Operation Serval, with 1,800 troops actually deployed in country. ${ }^{157}$ These forces consisted of multiple French army and marine units, seven fighter aircraft, fifteen helicopters, two aerial reconnaissance aircraft, five tanker aircraft, two maritime patrol aircraft, one advanced surgical unit, and one detachment of special operations forces assets. ${ }^{158}$

${ }^{151}$ Bruce R. Shurkin, France's War in Mali: Lessons for an Expeditionary Army (Santa Monica, CA: RAND, National Defense Research Institute, 2014), accessed November 6, 2014, http://www.rand.org/pubs/research_reports/RR770.html, 8.

152 Ibid., 13.

153 Shurkin, 7-8.

154 Ibid., 13.

155 Ibid., 13-14.

156 Ibid., 14.

${ }^{157}$ French Embassy in New Delhi, “Operation SERVAL in Mali - Weekly Update: Launch of Operation SERVAL," 1.

158 Ibid., 1-2. 
With these initial forces that were increasing every day, the French launched ground offensive operations on January 15 to secure southern Mali and begin attempts to seize insurgent held areas in northern Mali. ${ }^{159}$ With assistance from Chadian and Nigerian forces, along with small Malian Tuareg contingents, Operation Serval began advancing rapidly north and securing the majority of the country by April 11, when the French began a planned withdrawal of some of its forces. ${ }^{160}$ Operation Serval continued past April, but the French took on more of a security assistance posture by providing assistance to Malian and African forces deployed in Mali. ${ }^{161}$ Throughout this period, France deployed over four thousand soldiers and conducted hundreds of combat air support, re-supply, re-fueling, and intelligence-gathering missions in this short time. However, especially early on in the operation, the French had to rely on its allies to transport, supply, and provide intelligence support to its forces.

Table 3. RMA/DOTMLFP for France

${ }^{159}$ Shurkin, 16.

${ }^{160}$ Etat major des Armees, “Operation Serval: Situation Update on Thursday 18 April 2013,” April 19, 2013, Ministre de la Defense, accessed November 28, 2014, www.defense.gouv.fr/english/content/view/full/201454.

161 Shurkin, 2. 


\begin{tabular}{|l|l|c|c|c|}
\hline Factor & $\begin{array}{l}\text { Does the nation-state } \\
\text { possess the necessary } \\
\text { capability? }\end{array}$ & $\begin{array}{c}\text { What do they } \\
\text { use to meet } \\
\text { this gap? }\end{array}$ & $\begin{array}{c}\text { What is the } \\
\text { identifiable gap? }\end{array}$ & $\begin{array}{c}\text { Has the gap } \\
\text { been } \\
\text { addressed? }\end{array}$ \\
\hline \multicolumn{5}{|c|}{ RMA } \\
\hline Technology & Yes & N/A & N/A & N/A \\
\hline Doctrine & Yes & N/A & N/A & N/A \\
\hline Organization & Yes & N/A & N/A & N/A \\
\hline \multicolumn{5}{|c|}{ YOTMLPF } \\
\hline Training & $\begin{array}{l}\text { No, did not possess } \\
\text { adequate capability } \\
\text { to move forces, } \\
\text { logistics, or provide } \\
\text { necessary } \\
\text { intelligence support }\end{array}$ & $\begin{array}{l}\text { Relied on } \\
\text { Allied } \\
\text { support }\end{array}$ & $\begin{array}{l}\text { Sufficient airlift, } \\
\text { refueling, and } \\
\text { intelligence } \\
\text { gathering } \\
\text { capability }\end{array}$ & No \\
\hline Yes & N/A & N/A & N/A \\
\hline Personnel & Yes & N/A & N/A & N/A \\
\hline Facilities & \multicolumn{4}{c}{} \\
\hline
\end{tabular}

Source: Created by author based on information gathered during research

Through the lens of RMA and DOTMLPF, Operation Serval provides a good case study to identify gaps necessary for limited combat operations. In terms of technology, French Forces showed they possessed all the necessary technology to conduct combat operations with no significant technological gaps, as the only threat not countered effectively was suicide bombers. ${ }^{162}$ While suicide bombers are a threat, the impact is typically minimal in the larger operational level unless a suicide bomber could strike a key node or command center at a key time. Otherwise, a suicide bomber would not significantly threaten operations. The French use of close air support and special operations forces with their combined arms formations while

emphasizing speed to disrupt the enemy forces shows proper execution according to their general doctrine. ${ }^{163}$ The French combined arms tactical subgroup organization provided the necessary

162 Shurkin, 24.

${ }^{163}$ Armee de Terre, General Tactics, 61, 64, 71. 
combined arms team that would allow the French to effectively integrate fire support and fire support coordination capabilities that allowed them to use artillery and attack air support. ${ }^{164}$ While the training level could be highlighted from the successful outcome, the benefits of the French bases in Africa afforded the French military with familiarity of the terrain, opportunity to practice joint operations over large areas, and accustomed to moving with little logistical support. ${ }^{165}$ The joint operations training proved to be highly successful in the French ability to use special forces and airborne units to seize airfields and await follow-on French and Malian ground forces. ${ }^{166}$ Additionally, General Bernard Barrerra, a French commander in Operation Serval, remarked that his officers could not believe how well the operation went and even asked their commander if he knew the year prior that they would be doing this operation due to their level of preparedeness. ${ }^{167}$ While France had some of the assets required to deploy and supply her forces, during the first three weeks, her allies provided seventy-five percent of the military airlift, transported seventy-five percent of the personnel and materiels, thirty percent of aerial refueling; and the United States provided an unspecified portion of intelligence support. ${ }^{168}$

${ }^{164}$ Shurkin, 28-29. The combined arms tactical subgroup is actually called a sousgroupement tactique interarmes and is approximately the size of a reinforced infantry company with organic command and logistics, engineering, and armor platoons.

165 Oliver Tramond and Philippe Seigneur, “Operation Serval: Another Beu Geste of France in Sub-Saharan Africa?” Military Review (November - December 2014): 80.

${ }^{166}$ Ibid., 82.

167 Jean-Dominique Merchet, “General Barrera: Mes Ordres Etaient Clairs: Detruisez les Djihadistes!” L'Opinion, accessed November 28, 2014, www.lopinion.fr/11-juillet-2013/generalbarrera-mes-ordres-etaient-clairs-detruisez-djihadistes-1942.

${ }^{168}$ Shurkin, 2-3. 
France freely identifies this problem and states in her defense white paper that she will rely on the principle of pooling with their European partners to mitigate their risk in air transport, intelligence, and air-to-air refueling. ${ }^{169}$ While the French had planned to work with African forces and relied heavily on them after they began deploying in theater, the French forces were adequate in numbers and skills to accomplish their mission. Basing for this operation was sufficient due to French forces already being located in neighboring states. As mentioned previously, these bases provided familiarity with the regioin and established a military force with equipment that did not need to move as far as other units. ${ }^{170}$ Similar to British operations in Sierra Leone, the French possessed capability gaps in their materiel, but unlike the British, were well prepared with their forward basing.

\section{China's Current Expeditionary State}

From analyzing the expeditionary operations for Britain and France across RMA and DOTMLPF, one can begin to see the vast amount of factors that a nation needs to be able to conduct operations beyond their shores. These factors change depending on the culture and objective of a country; however, the model provides a beneficial planning guide, especially in terms of China. To determine what expeditionary operations China can conduct currently, the author will attempt to use independent sources to confirm what operations China has conducted, and how well they performed the operation.

As China has not conducted combat operations since 1979, the operations the author can analyze are limited to a disaster relief operation within China and a NEO in Libya. The disaster

${ }^{169}$ Ministre de la Defense, French White Paper: Defence and National Security, 2013, April 29, 2013, Ministre de la Defense, accessed November 9, 2014, www.defense.gouv.fr/ english/content/download/26186/2393586/file/White\%20paper\%20on\%20defense\%20\%202013. pdf, 86.

170 Tramond and Seigneur, 81. 
relief operation provides an indication of China's capability to conduct a large operation within its own borders and serve as a foundation for examining her expeditionary operations. The NEO provides an iterative increase in complexity and difficulty due to the distances the Chinese had to traverse and the uncertainty of their operational environment.

While one may wonder how a natural disaster inside of a state's borders could serve as a test for expeditionary capabilities, one must understand the geography and extent of the damage to the region. On May 12, 2008, a magnitude 7.9 earthquake struck Sichuan Province in southwest China. The earthquake killed more than 87,000 people, dislocated 4.8 million people, cost the Chinese government over $\$ 137$ billion dollars to rebuild, and destroyed over 1.5 million houses. ${ }^{171}$ The devastated area was located in a remote, mountainous region where the earthquake and subsequent landslides destroyed, damaged, or blocked most land and river routes.

Additionally, the disaster disrupted telecommunications for the area, with fog and rain further impeding delivery of support. ${ }^{172}$ This situation closely resembles a foreign humanitarian assistance mission similar to one the United States or another nation would have to conduct, but with far less distance to be covered.

The Chinese government responded to this natural disaster with massive amounts of civilian and military aid, mobilizing over 130,000 military members from all the services and specialties to assist in the Sichuan province. ${ }^{173}$ China possessed the necessary technology to

171 James Daniell, “Sichuan 2008: A Disaster on an Immense Scale,” BBC News, May 8, 2013, accessed December 2, 2014, http://www.bbc.com/news/science-environment-22398684.

${ }^{172}$ Committee on Disaster Risk Reduction, Implementation of the Hyogo Framework for Action in Asia and the Pacific: Case Study: The National Disaster Management System of China and Its Response to the Wenchuan Earthquake (Bangkok, Thailand: United Nations Economic and Social Council, December 30, 2008), accessed August 4, 2014, http://www.unescap.org/idd/ events/cdrr-2009/CDR_2E.pdf, 4.

173 Jake Hooker, “Quake Revealed Deficiencies of China’s Military,” The New York Times, July 2, 2008, accessed December 2, 2014, http://www.nytimes.com/2008/07/02/world/ asia/02china.html?pagewanted=all\&_r=0. 
overcome the telecommunications disruption caused by the quake, but suffered problems in several other areas. The combination of poor logistical coordination and lack of specialized training serve as indicators that there are gaps in their doctrine. ${ }^{174}$ The Chengdu Military Region Logistics Department (organization responsible for coordinating PLA disaster relief response in the region) highlighted this lack of coordination by pointing out their command and control structure was insufficient in acquiring adequate logistical support among military and civilian agencies. ${ }^{175}$ The lack of specialized units responsible for natural disaster relief operations show a combined gap in organization and training. As one analyst noted, the deployment of such a large number of service members could serve as an indicator that the Chinese military did not possess the adequate number of specialized troops that could handle disaster relief operations, much less FHA. ${ }^{176}$ An additional shortcoming noted by one Chinese expert was that out of 6,500 paratroopers deployed to the area, only fifteen ended up dropping into the region. As the analyst further highlights, the Chinese military should have delivered the paratroopers within two hours, not the forty-four hours it actually took. ${ }^{177}$ This failure to deliver paratroopers into their target area within a reasonable time, given the weather, is an indicator of lack of proper training in airborne operations. While the airborne operations are not typically part of the disaster relief operations, the failure to be able to conduct a combat operation in support of a peacetime mission

${ }^{174}$ Ibid.

${ }^{175}$ Abraham M. Denmark, "PLA Logistics 2004-2011: Lessons Learned in the Field,” in Learning by Doing: The PLA Trains at Home and Abroad (Carlisle, PA: Strategic Studies Institute, US Army War College, 2012), accessed December 2, 2014, http://www.dtic.mil/get-trdoc/pdf?AD=ADA570772, 304-307.

${ }^{176}$ Nirav Patel, “China Disaster Relief Operations: Identifying Critical Capability Gaps,” Joint Forces Quarterly, no. 52 (1st Quarter 2009): 113, accessed December 2, 2014, http://ndupress. ndu.edu/portals/68/Documents/jfq/jfq-52.pdf.

${ }^{177}$ Hooker. 
is a serious indicator in the Chinese militaries capabilities. Another major gap in China's capabilities was her ability to move large equipment by air to assist in peace operations. ${ }^{178}$ As already pointed out, the Chinese military has a deficiency in personnel trained to conduct disaster relief operations. There were no noticeable problems with facilities, primarily due to the operations taking place within China’s borders.

With all these significant gaps, the Chinese military has begun working to overcome these deficiencies, most notably through improvement in its doctrine, organization, training, and materiel. In a 2012 defense white paper, the Chinese emphasized disaster relief and FHA as key components of its national defense strategy. ${ }^{179}$ Additionally, the People’s Liberation Army had conducted a multitude of joint and multilateral training exercises, to include two airborne operations, aimed at improving their disaster relief and FHA mission capabilities. ${ }^{180}$ Additionally, the People's Liberation Army Air Force (PLAAF) is currently testing large transport aircraft to increase its strategic lift capability of personnel and heavy equipment. ${ }^{181}$ While these changes and additions are not assurances that China can unilaterally conduct an FHA or disaster relief operation effectively, this information highlights that she is improving in these areas.

China's successful NEO in Libya provides a look at some of these improvements. In February 2011, peaceful demonstrations in Libya grew into open civil war following President

${ }^{178}$ Hooker.

${ }^{179}$ Ministry of National Defense of The People’s Republic of China, The Diversified Employmemt of China's Armed Forces (Beijing, China: Information Office of the State Council, April 16, 2013), accessed January 20, 2015, http://eng.mod.gov.cn/Database/WhitePapers/ 2012.htm, sect. V.

${ }^{180}$ Ibid. Additional information in regards to the exercises is found in Office of the Secretary of Defense, Annual Report to Congress: Military and Security Development Involving the People's Republic of China 2014 (Washington, DC: Department of Defense, April 24, 2014), accessed February 3, 2015, www/defemse/gov/pubs/2014_DoD_China_Report.pdf, 80-83.

${ }^{181}$ Office of the Secretary of Defense, Annual Report to Congress: Military and Security Development Involving the People's Republic of China 2014, 18. 
Muammar al-Qadhafi's government brutally suppressing these protests, which then led to major fighting between anti-government and government forces for over six months. ${ }^{182}$ Within a few weeks, the violence between Libyan and anti-government forces, along with random violence against foreign nationals, had spread to the point where China and other nations decided to begin evacuating their citizens. ${ }^{183}$ The Chinese government deployed civilian and military aircraft, to include four of their strategic lift aircraft, one frigate with limited helicopter capacity, and chartered civilian air and sea vessels. ${ }^{184}$ Within ten days, the Chinese successfully evacuated over 35,000 Chinese citizens. ${ }^{185}$ The significance of this operation was that this was China's largest and fastest evacuation of Chinese citizens, covered the most distance, and marks the first time the PLAN and PLAAF conducted a NEO. ${ }^{186}$

Through analysis of multiple reports and newspaper articles, the Chinese government or military did not have any noticeable gaps with technology, doctrine, organization, training, and personnel during the NEO. However, there are significant gaps in materiel and possibly facilities.

${ }^{182}$ United Nations Security Council, Report of the Assessment Mission on the Impact of the Libyan Crisis on the Sahel Region: December 07 - 23, 2011, United Nations Security Council, Report, accessed December 03, 2014, http://www.securitycouncilreport.org/atf/cf/ \%7B65BFCF9B-6D27-4E9C-8CD3-CF6E4FF96FF9\%7D/Libya\%20S\%202012\%2042.pdf, 2.

183 梁军, “China Evacuates Nationals from Chaotic Libya,” People’s Daily Online, accessed December 3, 2014, http://en.people.cn/90001/90776/90883/7296633.html.

${ }^{184}$ Roy Kamphausen, David Lai, and Travis Tanner, eds., Assessing the People's Liberation Army in the Hu Jintao Era (Carlisle, PA: Strategic Studies Institute and US Army War College Press, 2014), accessed December 2, 2014, http://www.strategicstudiesinstitute.army.mil/ pubs/display.cfm?pubID=1201, 477.

185 Wang Guanqun, “35,860 Chinese Evacuated from Unrest-Torn Libya,” Xinhuanet, March 3, 2011, accessed December 3, 2014, http://news.xinhuanet.com/english2010/china/201103/03/c_13759456.htm.

${ }^{186}$ Denmark, 313. 
As one author cites, the significant role of civilian aircraft and ships (operating under direction from the Chinese government) highlights a shortcoming in strategic lift capability.

Additionally, the PLA's reliance on civilian airports to fuel its aircraft may be an indication that they lack sufficient air refueling capability. ${ }^{187}$ In addition to strategic lift, the small number of amphibious assault ships in the region with helicopter lift capability reinforced China's reliance on civilian aircraft and shipping. As mentioned previously, the PLA's reliance upon civilian airports indicates a lack of basing that is necessary to project aircraft that distance. However, the Chinese military is currently increasing their strategic lift and aerial refueling capability to address these gaps. ${ }^{188}$ While these gaps in terms of materiel and facilities surely impeded and degraded operations, the Chinese were able to successfully deploy a naval frigate and four transport aircraft into the Mediterranean, and continue to work towards improving their projection capability. ${ }^{189}$

With these gaps identified in FHA and NEO operations, the next progression in the spectrum of military operations falls within major combat operations. Due to a lack of a recent example of Chinese major combat operations that would identify gaps following analysis through RMA and DOTMLPF, the US military will be used as the model due to their ability to unilaterally project power over much of the globe, even into denied environments. ${ }^{190}$ The specific

${ }^{187}$ Denmark, 314.

${ }^{188}$ Office of the Secretary of Defense, Annual Report to Congress: Military and Security Development Involving the People’s Republic of China 2014, 17.

${ }^{189}$ Denmark, 314.

${ }^{190}$ Modern examples of these type of operations are Operations Enduring Freedom and Iraqi Freedom. 
model that depicts the range of military operations from a US perspective is the ability to conduct a FEO. A joint FEO seizes and holds a lodgment against armed opposition, usually for follow-on operations. ${ }^{191}$ One specific capability of joint FEO is the amphibious assault operation, which is an operation that involves forces conducting a FEO from the sea. ${ }^{192}$ This specific operation closely aligns with the Chinese term for an amphibious invasion, the Joint Island Landing Campaign. ${ }^{193}$ This complex operation relies on joint operations to successfully establish a beachhead and continue pushing forces inland along with supplies. ${ }^{194}$ While Taiwan is the focus of this operation, the description of the operation closely aligns with US categorization of amphibious assault operations. Additionally, the majority of US concerns with China centered on China's actions and intentions in the East and South China Seas, the Western Pacific, and the Indian Ocean. ${ }^{195}$ The combination of air superiority, sea control, and continuous sustainment are the vital aspects of any FEO and required to provide the operation a chance of success. To assess China's ability to accomplish these functions, she must be able to integrate these aspects of FEO across RMA and DOTMLPF to show they can perform these tasks.

Technology

Over the past two decades, China has steadily sustained her increasing defense

191 JP 3-18, I-1.

192 Ibid., I-8.

${ }^{193}$ Cordesman, 368.

${ }^{194}$ Office of the Secretary of Defense, Annual Report to Congress: Military and Security Development Involving the People's Republic of China 2014, 55.

${ }^{195}$ US Congress, Senate, Statement of Admiral Locklear, 9. 
expenditures, resulting in a significant increase in military technology development and procurement. ${ }^{196}$ These increases in technology are most noticeable in China's increased A2/AD capabilities. While the Chinese state that these capabilities are defensive in nature, they possess both offensive and defensive characteristics and can assist in air superiority and sea control. The specific $\mathrm{A} 2 / \mathrm{AD}$ technologies that are notably dual use are the medium range ballistic missiles, anti-ship missiles, air force technology, and command and control capabilities. The Chinese military can use its medium range ballistic missiles as anti-ship missiles with ranges up to three thousand kilometers. ${ }^{197}$ The ability to target ships, especially capital ships, adds a valuable means to maintain sea control by allowing the Chinese to target enemy ships and land targets beyond the first island chain, thus disrupting enemy forces and ships responding from outside the operational area. ${ }^{198}$ In addition to the A2/AD technologies, the PLAN is using indigenous means and the purchase of advanced Russian submarines to steadily increase its development of quieter and harder to detect nuclear and non-nuclear submarines. ${ }^{199}$ While the purchase of the aircraft carrier, Liaoning, is not thought to serve as an immediate increase in force projection capabilities, the vessel can serve as an experimental platform that allows China to train, improve, and refine their carrier flight integration and other naval maneuvers to improve their capabilities dramatically with the arrival of new aircraft carriers. ${ }^{200}$ In addition to the aircraft

${ }^{196}$ Office of the Secretary of Defense, Annual Report to Congress:Military and Security Developments Involving the People's Republic of China 2014, ii.

${ }^{197}$ Annual Report to Congress:Military and Security Developments Involving the People's Republic of China 2014, 7. See also Cordesman, 290.

198 Ibid., 7.

${ }^{199}$ Ronald O’Rourke, Congressional Research Service Report for Congress RL33153, China Naval Modernization: Implications for U.S. Navy Capabilities - Background and Issues for Congress (Washington, DC: Library of Congress, August 5, 2014), accessed September 30, 2014, http://fpc.state.gov/documents/organization/230967.pdf, 7-15.

${ }^{200}$ Ibid., 17-18, 23-24. 
carrier technology, the PLAN is building new surface comabatants that incorporate stealthy hull designs that allows them to avoid detection. ${ }^{201}$ Finally, the People’s Liberation Army - Army (PLAA) has improved its army aviation units with precision-guided munitions, providing better air defense, creating an advanced command and control and ISR network that will improve air defense, aviation, and ground-air coordination that helps ensure air superiority. ${ }^{202}$ All of these capabilities significantly improve China's ability to gain and maintain air superiority and sea control. However, one glaring deficiency that lowers their standoff capability is China's lack of accurate targeting information beyond the first island chain. This lack of targeting information reduces their capability to maintain air superiority and sea control against a near peer competitor. ${ }^{203}$ Without proper air superiority, operations aimed at sea control and sustainment would be degraded, leading to a potential defeat during an amphibious assault.

Doctrine

While stated Chinese military policy is one focused on defensive measures, the doctrinal changes indicate more that expeditionary operations to include amphibious assault is not out of the realm of possibility (other than Taiwan). ${ }^{204}$ This military policy provides overarching guidance that describes their current and future development and their overall operating concepts at the strategic level. ${ }^{205}$ At the operational level, the Chinese doctrine builds on these concepts by

${ }^{201}$ O’Rourke, 24, 30.

${ }^{202}$ Annual Report to Congress:Military and Security Developments Involving the People's Republic of China 2014, 10.

${ }^{203}$ Ibid., 32.

204 The People's Republic of China, The Diversified Employment of China's Armed Forces, 1.

${ }^{205}$ Cordesman, 123-127. 
focusing on modernization, joint operations, combined arms maneuver, and improving logistics support. The Chinese efforts of modernization focus on being able operate in a network centric environment that allows them to coordinate and link geographically dispersed units and capabilities into unified action. ${ }^{206}$ This capability increases the Chinese military’s ability to execute complex offensive operations through time and space. Additionally, the Chinese military focuses on "integrated joint operations” that requires the PLA to operate between multiple services and enhance combat power. ${ }^{207}$ The Chinese military expands upon this joint concept by conducting integrated firepower operations between artillery, air forces, missile strikes, and information warfare operations, along with increasing campaign mobility through large-scale airmobile formations. ${ }^{208}$ One final consideration is the PLAA's change from theater defense to trans-theater mobility. ${ }^{209}$ While Chinese military doctrine provides a framework for defending against outside threats and maintaining internal security and stability, the methods and concepts discussed above provide a dual use model that can be used to project power. Although the ability to review Chinese doctrine is limited due to lack of transparency and translated materiel, the general military concepts present no noticeable gaps.

\section{Organization}

The Chinese military possesses all the necessary organizations to ensure air superiority and sea control, but as their response to the Sichuan Earthquake and the Libyan NEO highlighted,

${ }^{206}$ Annual Report to Congress: Military and Security Development Involving the People's Republic of China 2014, 12.

${ }^{207}$ Cordesman, 127.

${ }^{208}$ Ibid., 135-136. Forces, II.

${ }^{209}$ The People's Republic of China, The Diversified Employment of China's Armed 
their ability to support their operations logistically is inadequate. In response to their noted shortcomings in these operations, the PLA developed Joint Logistics Sub-Departments. Joint Logistics Sub-Department are ad-hoc organizations designed to serve as logistics support brigades that use military and civilian personnel and materiel resources, pushing them as far forward as possible to provide adequate support. ${ }^{210}$ In addition to her logistical restructure, the 2012 Chinese Defense White Paper highlighted the People Liberation Army - Army is reorienting from being able to operate in only one theater, but to be able to operate in more than one theater due to an emphasis on lighter units, special operations forces, and more digitalized units. ${ }^{211}$ While lighter units and more digitized forces could provide more flexibility and extend the projection capabilities of Chinese ground forces, the continuous logistical shortcomings in terms of "infromatized logistic equipment" and maintance of technical equipment negate most of the effectiveness of this new unit infrastructure. ${ }^{212}$ Although the PLA is revamping its logistical organization, this reliance on ad-hoc organizations could be problematic in combat operations. While this model should prove sufficient in most operations short of combat, the reliance on adhoc organizations could prove problematic in a wartime environment where the threat of enemy action and communication degradation is a valid concern. The ad-hoc JLSDs present a gap in the ability for Chinese forces to maintain support for its forces in the case of an amphibious operation.

${ }^{210}$ Cordesman, 137.

${ }^{211}$ The Diversified Employment of China's Armed Forces, II.

${ }^{212}$ Chase et al, 80 . 
Training

Over the past several years, China has conducted numerous unilateral, bilateral, and multilateral exercises that have improved her capabilities and helped the Chinese recognize deficiencies. In October 2013, the Chinese navy conducted its largest navy exercise in openocean utilizing all three fleets. ${ }^{213}$ The PLAN exercise is significant in that it provides Chinese forces with experience operating beyond the first island chain and acclimatizes them to operating further from their shores. This capability is essential to conducting sea control operations at the edge of the first island chain and beyond. Additionally, the PLAA and PLAAF conducted largescale joint operations in September and October of 2013. ${ }^{214}$ The Japanese Ministry of Defense assessed that the Chinese conducted these exercises to specifically improve their capabilities to project ground forces into distant areas and improve their logistical capabilities. ${ }^{215}$ Additionally, these joint exercises provide familiarity between air and ground forces that are vital to modern combat, and afford a critical ability to coordinate ground-air operations in an air superiority fight. Finally, some analysts estimate one-third to one-quarter of all PLA forces have received some type of amphibious warfare training. ${ }^{216}$ Finally, PLA is working to improve its military education by trying to increase the proficiency for officers and non-commissioned officers to be able to leverage all the technology that is required to conduct complex forcible entry operations. ${ }^{217}$

${ }^{213}$ Office of the Secretary of Defense, Annual Report to Congress: Military and Security Development Involving the People's Republic of China 2014, i.

${ }^{214}$ Ibid.

215 Japan Ministry of Defense, Defense of Japan 2014 (Tokyo, Japan: Urban Connections, November 25, 2014), accessed December 7, 2014, http://www.mod.go.jp/e/publ/w_paper/ebook/2014/_SWF_Window.html, 38, 39.

${ }^{216}$ Cordesman, 177.

${ }^{217}$ Annual Report to Congress: Military and Security Development Involving the People's Republic of China 2014, 12. 
This number shows a growing capability to project power and place forces ashore outside of Chinese territory.

Materiel

With the continued increase in military spending providing key equipment and weapons procurement, the Chinese military possesses an abundance of weapons and equipment, yet a shortage in certain areas that are necessary for an amphibious assault. The large amount of ballistic missiles increases the lethality of the Chinese military capabilities and improves their ability to gain and maintain air superiority through strikes on enemy airfields and air defense sites, and sea control through targeting of capital ships. ${ }^{218}$ In addition to their ballistic missiles, the Chinese PLAN has the largest number of capital ships, submarines, and amphibious warfare ships in Asia, while continuing to increase the number of submarines and other ships. ${ }^{219}$ This increased number and capability greatly enhance the Chinese ability for sea control operations, improves their ability to gain air superiority using surface-to-air firing capabilities from its ships, and the sustainment of forces through sustaining prolonged force projection operations through its amphibious ships. As noted by the Japanese Defense White Paper, these improvements in the PLAN's capabilities could be a sign that China wants to begin operating outside of the first island chain. ${ }^{220}$ In order for the PLAN to project forces beyond its shores, they rely on the world's largest amphibious assault force made up of landing ships, tank (LST), landing ships, medium

${ }^{218}$ Cordesman, 290.

${ }^{219}$ Office of the Secretary of Defense, Annual Report to Congress: Military and Security Development Involving the People's Republic of China 2014, 9.

${ }^{220}$ Japan Ministry of Defense, Defense of Japan 2014, 39. 
(LSM), and amphibious transport docks. ${ }^{221}$ These ships provide the PLAN with the ability to transport troops and equipment, provide command and control elements, and supply a limited air component in the form of helicopter platforms. These platforms, most notably the larger amphibious transport dock, provide rotar wing support to the range of military operations. ${ }^{222}$ These assets allow the PLAN to project forces for non-combat or limited combat operations around the world to include anti-piracy operations off Somalia. ${ }^{223}$

In addition to possessing a very large navy, the PLAAF is the third largest air force in the world and modernizing its fleet at a rapid pace. The PLAAF is increasing its capabilities by bringing more fourth and fifth generation aircraft online to replace its dated third generation fighters. ${ }^{224}$ Another air superiority capability is the PLAAF’s suface-to-air missile system, which is one of the largest advanced systems in the world. ${ }^{225}$ This missile system vastly limits the effectiveness of enemy aircraft operating within range of the platforms, providing a decisive advantage to China in the battle for air superiority within range of these systems.

${ }^{221}$ Daniel J. Kostecka, "From the Sea: PLA Doctrine and the Employment of Sea-Based Airpower,” Naval War College Review 64, no. 3 (Summer 2011): 18-19. For comparative purposes, China has approximately sixty amphibious ships while the US Navy has 29 as of November 2011. Congressional Budget Office, An Analysis of the Navy's Amphibious Warfare Ships for Deploying Marines Overseas, (November 2011), accessed April 09, 2015, http://www.cbo.gov/sites/default/files/11-18-AmphibiousShips.pdf. Of note, these numbers do not indicate a qualitiative assessment.

222 Ibid., 12.

${ }^{223}$ O’Rourke, 81, 82.

${ }^{224}$ Office of the Secretary of Defense, Annual Report to Congress: Military and Security Development Involving the People's Republic of China 2014, 8-9. The capability improvement from fourth to fifth generation fighter aircraft revolves primarily around advanced avionics and the use of low observable "stealth" technology. Examples for the United States are the F-35 and China the J-20. "Fighter Aircraft Generations," GlobalSecurity.org, last modified October 24, 2014, accessed April 09, 2015, http://www.globalsecurity.org/military/world/fighter-aircraft-gen1.htm.

$$
{ }^{225} \text { Ibid., } 10 .
$$


While these capabilities appear to provide great advantages to China's ability to conduct amphibious operations, there are some notable shortcomings. Their large submarine force is very capable in the litorral regions of China, but their limited number of nuclear propelled attack submarines limits their ability to project power and conduct sea control operations effectively beyond the first island chain. ${ }^{226}$ An additional constraint on sea control and air superiority is their aircraft carrier. The aircraft carrier provides a fantastic capability to project air power that can assist in air superiority and sea control. Although China possesses one aircraft carrier, analysts do not expect an operational air wing until 2015. ${ }^{227}$ An additional naval constraint is the PLAN's amphibious assault force. While the previously mentioned Chinese LST, LSM, and amphibious transport docks make up the largest amphibious force in the world, they still do not possess enough capacity to move sufficient forces for combat operations into a theater beyond its littorals. These ships cannot transport enough troops and equipment, nor provide sufficient vertical lift capacity, to land more than two divisions ashore, which is insufficient against an opposition force similar to those required to conduct a FEO against Taiwan. ${ }^{228}$ An additional gap in in air superiority and sea control is that the the majority of its fighters are third generation, placing China at a disadvantage in a battle with a near peer competitor and possibly prevent them from being able to gain air superiority. ${ }^{229}$ An overarching restraint is China’s difficulties incorporating efficient command, control, communication, computers, and intelligence, surveillance, and reconnaissance technology into its structure. Poor implementation and service rivalries degrade

${ }^{226}$ Cordesman, 245.

${ }^{227}$ Office of the Secretary of Defense, Annual Report to Congress: Military and Security Development Involving the People's Republic of China 2014, 7.

${ }^{228}$ Kostecka, 19.

${ }^{229}$ Chase et al., 103. 
this capability and limit its role as an enhancement on force proejection capabilities. ${ }^{230}$ The final limitation is the lack of strategic airlift that limits their sustainment ashore capability. The Chinese PLAAF is currently testing a large transport aircraft to being supplemental to their current limited fleet, but the numbers are still limited to above fourteen. ${ }^{231}$ In comparison, the United States possesses over 330 strategic lift aircraft. ${ }^{232}$ These limited numbers of nuclear attack submarines, aircraft carriers, and strategic lift serve as a gap in China’s ability to conduct amphibious operations beyond its near seas.

Personnel

If one were to ask the common person, what is the basic characteristic of the Chinese military, the answer would be all about the numbers. While the Chinese military has over 2.2 million personnel across the army, navy, and air force (not counting reserves or paramilitary forces), the Chinese military recognizes that sheer numbers are not the deciding factor if they want to fight a network centric mode of warfare as described in their doctrine. ${ }^{233}$ The PLA is currently changing its recruiting methods by not focusing on total numbers but aiming for personnel with higher levels of education and/or technical proficiency. ${ }^{234}$ This increased

${ }^{230}$ Kevin Pollpeter, "Towards and Integrated C4SISR System: Informatization and Joint Operations in the People's Liberation Army,” in The PLA at Home and Abroad: Assessing the Operational Capabilities of China's Military, ed. Roy Kamphausen, David Lai, and Andrew Scobell (Carlisle, PA: Strategic Studies Institute, US Army War College, 2010), 219-221.

${ }^{231}$ Cordesman, 268.

${ }^{232}$ Christopher A. Moulton, David T. Orletsky, Michael Kennedy, and Fred Timson, Reducing Long-Term Costs While Preserving a Robust Strategic Airlift Fleet: Options for the Current Fleet and Next-Generation Aircraft (Santa Monica, CA: RAND, Project Air Force, 2013), accessed December 9, 2014, http://www.rand.org/content/dam/rand/pubs/monographs/ MG1200/MG1238/RAND_MG1238.pdf., Xv

${ }^{233}$ Cordesman, 47.

${ }^{234}$ Cordesman, 168. 
proficiency is a prerequisite for and provides the PLA with the capability to conduct the complex joint operations necessary to obtain sea control, air superiority, and ensure logistical support. However, this transition from reliance on conscription to recruiting more qualified personnel serves as a potential indicator that the PLA recognizes a gap in its ability to fight modern network centric warfare.

Facilities

As highlighted during the British and French operations in Africa, appropriate basing facilities in the vicinity or at least operational reach through seabasing of one's forces is critical to mission success in any operation that involves combat. The United States possesses both appropriate basing facilities around the world and a developed seabasing concept. China appears to be attempting a "Chinese version” of basing through its "String of Pearls" and other seaport investments (See Figure 3). ${ }^{235}$ The Chinese String of Pearls is a phrase given to Chinese investments in seaports along the littoral regions of the Indian Ocean. ${ }^{236}$ In addition to the seaports in the Indian Ocean, the Chinese government has also invested in Greek and North African seaports. ${ }^{237}$ While some analysts argue that these investments are the precursor to PLAN bases, to date, none of these bases have appeared. ${ }^{238}$ While these ports may not serve as PLAN

${ }^{235}$ Virginia Marantidou, “Revisiting China’s 'String of Pearls' Strategy: Places 'with Chinese Characteristics' and Their Security Implications,” Issues \& Insights 14, no. 7 (June 2014): 1, accessed December 7, 2014, http://csis.org/files/publication/140624_issuesinsights_ vol14no7.pdf.

${ }^{236}$ Ibid. For a view of China's String of Pearls being used in a more militaristic way, review Brahma Chellaney, “Countering China's String of Pearls,” The Washington Times, May 6, 2013, accessed December 9, 2014, http://www.washingtontimes.com/news/2013/may/6/ countering-chinas-string-of-pearls/.

${ }^{237}$ Marantidou, 1.

238 Marantidou, 1-2. 
bases, they do provide the capacity for refueling, replenishment, crew rest, and low-level maintenance. ${ }^{239}$ These additional seaports extend the range of the PLAN; however, these places do not provide necessary capabilities to replenish military equipment or weapons. Although China possesses some capability to resupply at sea, the anti-piracy operations and the NEO in Libya expose the lack of sustainment capabilities. ${ }^{240}$ The lack of sustained full military logistics ability would greatly impede the Chinese military's ability to sustain its forces if they conducted a FEO beyond their near seas.

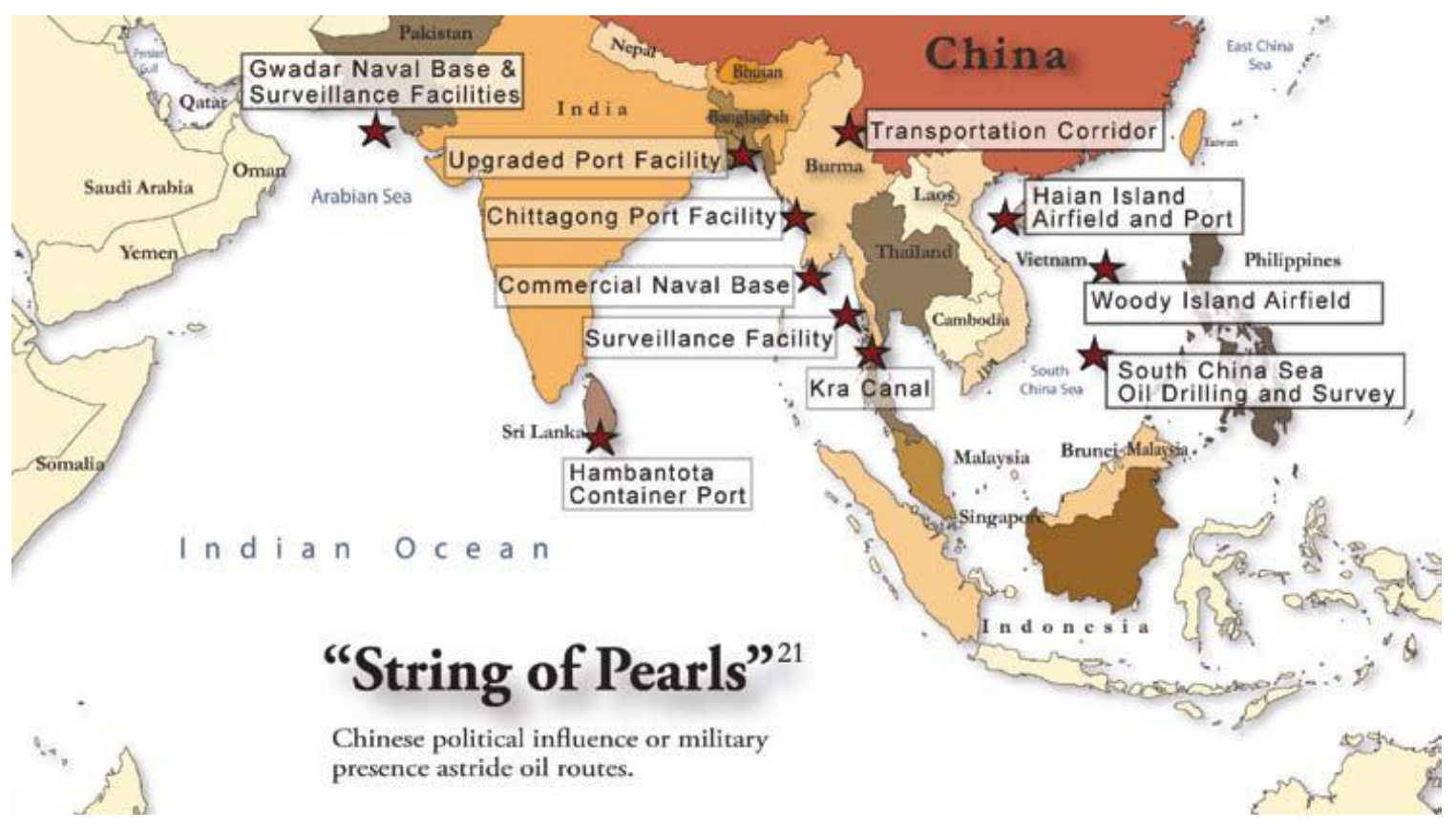

Figure 3. China’s String of Pearls

Source: Mark Tempest, “China’s Sea Lanes,”U.S. Naval Institute Blog, January 2009, accessed April 15, 2015, http://blog.usni.org/2009/01/03/chinas-sea-lanes/.

\section{Conclusion}

${ }^{239}$ Office of the Secretary of Defense, Annual Report to Congress: Military and Security Development Involving the People's Republic of China 2014, 39.

${ }^{240}$ Marantidou, 12. 
Although China’s large military expenditures has increased its force projection capabilities, she still cannot conduct all missions along the spectrum of military operations. While China experienced significant gaps in its disaster response operation in the Sichuan province, and showed capability gaps in the NEO in Libya, China's continuing development has overcome most of those issues and one can reason that China can now conduct military engagement, security cooperation, deterrence operations, crisis response, and limited contingency operations. However, due to gaps within RMA and DOTMLPF, China would not be able to sustain major operations or campaigns far from its littoral region.

Although China’s military has made great strides, its gaps in technology, organization, materiel, personnel, and facilities prevent them from achieving air superiority, sea control, or continuous sustainment in an area of operations beyond the First Island Chain. Technologically, the PLA lacks enough fourth or fifth generation fighters and the ability to collect targeting information beyond the first island chain, thus limiting their ability to gain air superiority and sea control. Organizational shortcomings in the ad-hoc Joint Logistics Sub-Departments could prove to be vulnerable in a combat situation and lead to a disruption in support to the ground forces. Materiel shortfalls are apparent in their limited number of nuclear attack submarines, aircraft carriers, amphibious assault ships, and strategic airlift. This prevents Chinese power projection beyond the first island chain and make them vulnerable to near peer competitors. The PLA's personnel shortfalls are simply an insufficient number of people that have the technical skills to operate the modern systems required for conducting amphibious operations. Finally, the lack of facilities to provide proper military resupply limits the PLA to Chinese near seas, and makes a FEO outside of that area nearly impossible.

While these gaps currently prevent China from conducting FEOs beyond the first island chain, China has sufficient capability to pose a threat to its neighbors. China’s current capabilities allow them to exercise increased influence in the South and East China Seas, and weld substantial 
coercive power towards US allies and partners in the region. These capabilities are not sufficient to allow China to conduct a FEO against the Japanese home islands or even Taiwan; however, these capabilities provide them with enough force projection to seize islands claimed by these allies and partners. ${ }^{241}$ This capacity to take contested islands in the Spratly or Senakaku island chains poses a significant security concern for the United States.

With these current capabilities defined, US defense analysts now must be aware of indicators that show increased capabilities that may allow China to progress to being able to conduct a FEO directly against our partners or allies. The first indicator is the production and procurement of more fourth or fifth generation fighters to increase their parity in terms of performance and technology. In addition to more fourth generation fighters, the PLA's production of or obtaining more ISR platforms and/or increasing their space-based technology capabilities would allow their current weapon systems to accurately engage targets beyond the first island chain. The second indicator is either a successful operation or exercise utilizing the Joint Logistics Sub-Departments. This indicator would imply China could now provide adequate logistics beyond their near seas, extending their power projection capabilities. The third indicator is China's acquisition of more modern or upgraded equipment such as nuclear attack submarines, amphibious assault ships, aircraft carriers, and strategic airlift. The final indicator can only be analyzed through observation in exercises or operations. The observation of the PLA successfully conducting a joint operation, using the full range of available technologies, while relying on seabasing or a forward base would be the last hurdle to China being able to conduct a FEO and other major operations.

The RMA and DOTMLPF assessment provides a comprehensive view of a military's capabilities because these tools allow one to analyze not only the equipment or technology a country possesses, but the ability of that country to utilize those assets. RMA and DOTMLPF

${ }^{241}$ Kostecka, 19. 
showed that while successful, Britain and France still needed assistance from other countries to ensure they could accomplish their objectives. China continues to progress its force projection capabilities; however, they have gaps in RMA and DOTMLPF that prevent them from progressing beyond the ability to conduct crisis response and limited contingency operations. The most important aspect of this RMA and DOTMLPF analysis is that it provided five indicators that defense analysts should focus on in order to assess China's capabilities to progress to the ability to conduct amphibious operations, a precursor to major operations and campaigns. 


\section{Bibliography}

Books

Alexander, Joseph H. Sea Soldiers in the Cold War: Amphibious Warfare, 1945-1991. Annapolis, MD: Naval Institute Press, 1995.

Bundu, Abass. Democracy by Force?: A Study of International Military Intervention in the Civil War in Sierra Leone from 1991-2000. Parkland, FL: Universal Publishers, 2001.

Corbett, Julian Stafford. Some Principles of Maritime Strategy. The Project Gutenberg ebook, 2005. Accessed February 8, 2015. www.gutenberg.org/ebooks/15076.

Denmark, Abraham M. "PLA Logistics 2004-2011: Lessons Learned in the Field.” In Learning by Doing: The PLA Trains at Home and Abroad, 297-336. Carlisle, PA: Strategic Studies Institute, US Army War College, 2012. Accessed December 2, 2014. http://www.dtic. $\mathrm{mil} /$ get-tr-doc/pdf?AD=ADA570772.

Dorman, Andrew M. Blair's Successful War: British Military Intervention in Sierra Leone. Military Strategy and Operational Art. Farnham, England: Ashgate, 2009.

Erickson, Andrew S. "Chinese Sea Power in Action: The Counterpiracy Mission in the Gulf of Aden and Beyond.” In The PLA at Home and Abroad: Assessing the Operational Capabilities of China's Military, edited by Roy Kamphausen, David Lai, and Andrew Scobell, 295-376. Carlisle, PA: Strategic Studies Institute, US Army War College, 2010.

Harris, David. Civil War and Democracy in West Africa: Conflict Resolution, Elections and Justice in Sierra Leone and Liberia. New York: I .B. Tauris, 2012. Accessed November 10, 2014. http://search.ebscohost.com/login.aspx?direct=true\&scope=site\&db=nlebk\& $\mathrm{db}=$ nlabk\&AN=433746.

Kamphausen, Roy, David Lai, and Travis Tanner, eds. Assessing the People's Liberation Army in the Hu Jintao Era. Carlisle, PA: Strategic Studies Institute and US Army War College Press, 2014. Accessed December 2, 2014. http://www.strategicstudiesinstitute.army.mil/ pubs/display.cfm?pubID=1201.

Kennedy, Paul M. Engineers of Victory: The Problem Solvers Who Turned the Tide in the Second World War. New York: Random House, 2013.

Van Creveld, Martin. Command in War. Cambridge, MA: Harvard University Press, 1985.

Warden, John. The Air Campaign: Planning for Combat. Fort Lesley J. McNair, Washington, DC: National Defense University Press, 1988. Accessed December 3, 2014. http://babel.hathitrust.org/cgi/pt?id=uiug.30112006718891;view=1up;seq=4.

Woods, Larry J. Military Interventions in Sierra Leone: Lessons from a Failed State. The Long War Series. Fort Leavenworth, KS: Combat Studies Institute Press, US Army Combined Arms Center, 2008. 


\section{Government Documents}

Air-Sea Battle Office. Air-Sea Battle: Service Collaboration to Address Anti-Access \& Area Denial Challenges, May 2013. US Department of Defense. Accessed October 30, 2014. http://www.defense.gov/pubs/ASB-ConceptImplementation-Summary-May-2013.pdf.

Arieff, Alex. Congressional Research Service Report for Congress R2664, Crisis in Mali. Washington, DC: Library of Congress, January 14, 2013. Accessed November 26, 2014. www.fpc.state.gov/documents/organization/203726.pdf.

Armee de Terre. General Tactics. Paris, France: Centre de Doctrine d’Emploi Des Forces, 2010.

Chairman Joint Chiefs of Staff. Joint Operational Access Concept (JOAC). Ver. 1. Washington, DC: Government Printing Office, January 17, 2012. Accessed September 30, 2014. http://www.defense.gov/pubs/pdfs/JOAC_Jan\%202012_Signed.pdf.

Chiefs of Staff. Joint Doctrine Publication 3-00, Campaign Execution. 3rd ed. Shrivenham, England: Ministry of Defence, 2009. Accessed November 20, 2014. https://www.gov.uk/ government/uploads/system/uploads/attachment_data/file/43329/20120829jdp300_ed3_c h1.pdf.

. Joint Doctrine Publication 3-52, Disaster Relief Operations. 2nd ed. Shrivenham, England: Ministry of Defence, 2008. Accessed November 4, 2014. https://www.gov.uk/ government/uploads/system/uploads/attachment_data/file/43340/jdp3522nded.pdf.

Cole, Ronald H. Operation Urgent Fury: Grenada. Washington, DC: Office of the Chairman of the Joint Chiefs of Staff, Joint History Office, 1997. Accessed February 12, 2015. http://www.dtic.mil/doctrine/doctrine/history/urgfury.pdf.

Committee on Disaster Risk Reduction. Implementation of the Hyogo Framework for Action in Asia and the Pacific: Case Study: The National Disaster Management System of China and Its Response to the Wenchuan Earthquake. Bangkok, Thailand: United Nations Economic and Social Council, December 30, 2008. Accessed August 4, 2014. http://www.unescap.org/idd/events/cdrr-2009/CDR_2E.pdf.

Commonwealth of Australia. Australian Defence Doctrine Publication 3.10, Noncombatant Evacuation Operations. Canberra, Australia: Defence Publishing Service, 2011. Accessed October 30, 2014. http://www.defence.gov.au/adfwc/Documents/Doctrine Library/ADDP/ADDP_3_10_Noncombatant_Evac_Ops.pdf.

Cordesman, Anthony. Chinese Military Modernization and Force Development: Chinese and Outside Perspectives. Washington, DC: Center for Strategic and International Studies, July 2, 2014. Accessed December 7, 2014. http://csis.org/files/publication/140702_ Chinese_MilBalance.pdf.

Congressional Budget Office. An Analysis of the Navy's Amphibious Warfare Ships for Deploying Marines Overseas, (November 2011). Accessed April 09, 2015. http://www.cbo.gov/sites/default/files/11-18-AmphibiousShips.pdf. 
Department of Defense. Quadrennial Defense Review 2014. Washington, DC: Department of Defense, March 4, 2014. Accessed September 30, 2014. http://www.defense.gov/pubs/ 2014_Quadrennial_Defense_Review.pdf.

Etat major des Armees. “Operation Serval: Situation Update on Thursday 18 April 2013,” April 19, 2013. Ministre de la Defense. Accessed November 28, 2014. www.defense.gouv.fr/ english/content/view/full/201454.

French Embassy in New Delhi. "Operation SERVAL in Mali - Weekly Update: Launch of Operation SERVAL,” January 18, 2013. Ministere des Affaires Etrangeres Et Du Developpment International. Accessed November 26, 2014. www.ambafrancein.org/IMG/pdf/Operation_Serval_in_Mali_-_Weekly_Update_1_-_18_Jan_2013.pdf ?8334/61135643f9105e86371821586e5c020d99111329.

Jabara, Cathy, Joanne Guth, Dylan Carlson, Justino De La Cruz, William Greene, Jeffrey Horowitz, Lin Jones, Alissa Tafti, Edward Wilson, William W. Gearhart, Logan Cobb, Laura Rodriguez, Edward Petronzio, Naomi Freeman, Daniel Shepherdson, David Lloyd, Russell Duncan, Jeremy Wise, Katherine Linton, Kimberly Lovejoy, Peg Hauseman, Cynthia Payne, Arona Butcher. The Year in Trade 2013: Operation of the Trade Agreements Program. Washington, DC: US International Trade Commission, July 2014. Accessed October 13, 2014. http://www.usitc.gov/publications/332/pub4481.pdf.

Japan Ministry of Defense. Defense of Japan 2014. Tokyo, Japan: Urban Connections, November 25, 2014. Accessed December 7, 2014. http://www.mod.go.jp/e/publ/w_paper/ebook/2014/_SWF_Window.html.

Joint Chiefs of Staff. Chairman of the Joint Chiefs of Staff Instruction 3010.02D, Guidance for Development and Implementation of Joint Concepts. Washington, DC: Government Printing Office, November 22, 2013. Accessed October 18, 2014. http://www.dtic.mil/ cjcs_directives/cdata/unlimit/3010_02.pdf.

. Joint Publication 1-02, Department of Defense Dictionary of Military and Associated Terms. Washington, DC: Government Printing Office, November 8, 2010 (as amended through January 2015). Accessed August 13, 2014. http://www.dtic.mil/doctrine/new_ pubs/jp3_0.pdf.

. Joint Publication 3-0, Joint Operations. Washington, DC: Government Printing Office, August 11, 2011. Accessed August 13, 2014. http://www.dtic.mil/doctrine/new_ pubs/jp3_0.pdf.

. Joint Publication 3-01, Countering Air and Missile Threats. Washington, DC: Government Printing Office, March 23, 2012. Accessed December 3, 2014. https://www.dtic.mil/doctrine/new_pubs/jp3_01.pdf.

. Joint Publication 3-02, Amphibious Operations. Washington, DC: Government Printing Office, July 18, 2014. Accessed December 1, 2014. http://www.dtic.mil/doctrine/new_ pubs/jp3_02.pdf. 
. Joint Publication 3-18, Joint Forcible Entry Operations. Washington, DC: Government Printing Office, November 27, 2012. Accessed December 10, 2014. http://www.dtic.mil/ doctrine/new_pubs/jp3_18.pdf.

. Joint Publication 3-29, Foreign Humanitarian Assistance. Washington, DC: Government Printing Office, January 3, 2014. Accessed February 12, 2015. http://www.dtic.mil/ doctrine/new_pubs/jp3_29.pdf.

. Joint Publication 3-32, Command and Control for Joint Maritime Operations. Washington, DC: Government Printing Office, August 7, 2013. Accessed December 8, 2014. http://www.dtic.mil/doctrine/new_pubs/jp3_32.pdf.

. Joint Publication 3-35, Deployment and Redeployment Operations. Washington, DC: Government Printing Office, January 31, 2013. Accessed September 30, 2014. http://www.dtic.mil/doctrine/new_pubs/jp3_35.pdf.

. Joint Publication 3-68, Noncombatant Evacuation Operations. Washington, DC: Government Printing Office, December 23, 2010. Accessed August 13, 2014. http://www.dtic.mil/doctrine/new_pubs/jp3_68.pdf.

Ministre de la Defense. French White Paper: Defence and National Security, 2013. Ministre de la Defense, April 29, 2013. Accessed November 9, 2014. www.defense.gouv.fr/english/ content/download/26186/2393586/file/White\%20paper\%20on\%20defense\%20\%202013. pdf.

Ministry of National Defense of The People's Republic of China. Chinese Defense White Paper, The Diversified Employment of China's Armed Forces. Beijing, China: Information Office of the State Council, April 16, 2013. Accessed February 3, 2015. http://eng.mod.gov.cn/Database/WhitePapers/2012.htm.

North Atlantic Treaty Organization. AAP-06, NATO Glossary For Terms and Definitions. 2014th ed. Brussels, Belgium: NATO Standardization Agency, 2014. Accessed February 5, 2015. http://nso.nato.int/nso/zPublic/ap/aap6/AAP-6.pdf.

. Allied Joint Publication 3, Allied Joint Doctrine for the Conduct of Operations. Ed. B. Brussels, Belgium: NATO Standardization Agency, March 2011. Accessed February 5, 2015. http://nso.nato.int/nso/zPublic/ap/ajp-3(b).pdf.

. Allied Joint Publication 3.3.3, Allied Joint Doctrine for Air-Maritime Coordination. Ed. A, Ver. 1. Brussels, Belgium: NATO Standardization Office, December 2014. Accessed February 5, 2015. http://nso.nato.int/nso/zPublic/ap/AJP-3.3.3\%20EDA\%20V1\% 20E.pdf.

Office of the Secretary of Defense. Annual Report to Congress: Military and Security Development Involving the People's Republic of China 2014. Washington, DC Department of Defense, April 24, 2014. Accessed February 3, 2015. www.defense.gov/ pubs/2014_DoD_China_Report.pdf. 
O’Rourke, Ronald. Congressional Research Service Report for Congress RL33153, China Naval Modernization: Implications for U.S. Navy Capabilities - Background and Issues for Congress. Washington, DC: Library of Congress, August 5, 2014. Accessed September 30, 2014. http://fpc.state.gov/documents/organization/230967.pdf.

Siegel, Adam B. Eastern Exit: The Noncombatant Evacuation Operation (NEO) from Mogadishu, Somalia, in January 1991. Alexandria, VA: Center for Naval Analyses, 1991.

United Kingdom Ministry of Defence and Republic of France French Joint Staff. Combined Joint Expeditionary (CJEF) User Guide. Shrivenham, England and Paris, France:

Development, Concepts and Doctrine Centre and Centre Interarmées de Concepts, de Doctrine et d'Expérimentations, 2012. Accessed February 5, 2015. http://www.cicde. defense.gouv.fr/IMG/pdf/20121218_np_cicde_dcdc_cjef-user-guide.pdf.

United Kingdom Royal Air Force. A Short History of the Royal Air Force. UK Crown. Accessed March 7, 2015. http://www.raf.mod.uk/rafcms/mediafiles/F21F8E7A_BD8A_55BA_ 43FA63F04FC5D6B4.pdf.

United Nations Security Council. "Sierra Leone - UNAMSIL - Facts and Figures,” 2005. United Nations. Accessed February 12, 2015. http://www.un.org/en/peacekeeping/missions/ past/unamsil/facts.html.

. "Sierra Leone - UNAMSIL - Mandate,” October 22, 1999. United Nations. Accessed November 18, 2014. http://www.un.org/en/peacekeeping/missions/past/unamsil/ mandate.html.

. Report of the Assessment Mission on the Impact of the Libyan Crisis on the Sahel Region: 7 to 23 December 2011, January 18, 2012. Security Council Report. Accessed December 3, 2014. http://www.securitycouncilreport.org/atf/cf/\%7B65BFCF9B-6D274E9C-8CD3-CF6E4FF96FF9\%7D/Libya\%20S\%202012\%2042.pdf.

. Report of the Secretary-General on the Situation in Mali: December 20, 2013 - March 26, 2014, March 26, 2013. United Nations. Accessed November 26, 2014. www.un.org/ en/ga/search/view_doc.asp?symbol=S/2013/189.

US Congress. House. Testimony of Dr. Larry Wortzel before the Armed Services Committee, US House of Representatives, November 20, 2013. 2013 Annual Report to Congress: China's Military Modernization, U.S.-China Security Relations, and China's Cyber Activities. US-China Economic and Security Review Commission. Accessed September 30, 2014. http://www.uscc.gov/Testimonies_Speeches/2013-annual-report-congresschina\%E2\%80\%99s-military-modernization-us-china-security.

. House. Testimony of Vice Chairman Dennis C. Shea before the Armed Services Committee, US House of Representatives, November 20, 2013. 2013 Annual Report to Congress: China's Maritime Disputes in the East and South China Seas, and the CrossStrait Relationship. US-China Economic and Security Review Commission. Accessed September 30, 2014. http://www.uscc.gov/Testimonies_Speeches/2013-annual-reportcongress-china\%E2\%80\%99s-maritime-disputes-east-and-south-china-seas. 
Senate. Statement of Admiral Samuel J. Locklear, U.S. Navy Commander, U.S. Pacific Command Before The Senate Committee On Armed Services On U.S. Pacific Command Posture, March 25, 2014. Accessed September 30, 2014. US Senate Committee on Armed Services. http://www.armed-services.senate.gov/imo/media/doc/Locklear_03-2514.pdf.

US Department of State, Office of the Historian. "Chronology of U.S.-China Relations, 17842000.” US Department of State. Accessed October 30, 2014. https://history.state.gov/countries/issues/china-us-relations.

\section{Journals/Periodicals}

Chellaney, Brahma. “Countering China’s String of Pearls.” The Washington Times. May 6, 2013. Accessed December 9, 2014. http://www.washingtontimes.com/news/2013/may/6/ countering-chinas-string-of-pearls/.

Connaughton, Richard. "The Mechanics and Nature of British Interventions into Sierra Leone (2000) and Afghanistan (2001-2002).” Civil Wars 5, no. 2 (March 2002): 77-95.

French, Howard W. “China’s Dangerous Game.” The Atlantic, October 13, 2014. Accessed March 31, 2015. http://www.theatlantic.com/magazine/archive/2014/11/chinasdangerous-game/380789/.

Hooker, Jake. “Quake Revealed Deficiencies of China’s Military.” The New York Times, July 2, 2008. Accessed December 2, 2014. http://www.nytimes.com/2008/07/02/world/asia/ 02china.html?pagewanted=all\&_r=0.

Jervis, Robert. “Dilemmas About Security Dilemmas.” Security Studies 20, no. 3 (July 2011): 416-423.

Koesnikov-Jessop, Sonia. “Shippers Examine Advantages of Fuel Change.” The New York Times, January 19, 2011. Accessed February 8, 2015. www.nytimes.com/2011/01/20/business/ global/20iht-rbogship.html?pagewanted=all\&_r=0.

Kostecka, Daniel J. "From the Sea: PLA Doctrine and the Employment of Sea-Based Airpower." Naval War College Review 64, no. 3 (Summer 2011): 11-31.

Marantidou, Virginia. "Revisiting China’s 'String of Pearls' Strategy: Places 'with Chinese Characteristics' and Their Security Implications.” Issues \& Insights 14, no. 7 (June 2014). Accessed December 7, 2014. http://csis.org/files/publication/140624_ issuesinsights_vol14no7.pdf.

Merchet, Jean-Dominique. "General Barrera: Mes Ordres Etaient Clairs: Detruisez les Djihadistes!” L'Opinio. Accessed November 28, 2014. www.lopinion.fr/11-juillet2013/general-barrera-mes-ordres-etaient-clairs-detruisez-djihadistes-1942.

Patel, Nirav. “China Disaster Relief Operations: Identifying Critical Capability Gaps.” Joint Forces Quarterly, no. 52 (Quarter 2009): 111-117. Accessed December 2, 2014. http://ndupress.ndu.edu/portals/68/Documents/jfq/jfq-52.pdf. 


\section{Online Sources}

Daniell, James. “Sichuan 2008: A Disaster on an Immense Scale.” BBC News, May 8, 2013, Accessed December 2, 2014. http://www.bbc.com/news/science-environment-22398684.

Dunn, Candace. "China Is Now the World's Largest Net Importer of Petroleum and Other Liquid Fuels,” March 24, 2014. US Energy Information Administration. Accessed February 8, 2015. www.eia.gov/todayinenergy/detail.cfm?id=15531.

GlobalSecurity.org. "Fighter Aircraft Generations.” Last modified October 24, 2014. Accessed April 09, 2015. http://www.globalsecurity.org/military/world/fighter-aircraft-gen-1.htm.

GlobalSecurity.org. “People’s Liberation Navy - Offshore Defense.” Last modified November 07, 2011. Accessed April 09, 2015. http://www.globalsecurity.org/ military/world /china/plan-doctrine-offshore.htm.

Larive, Maxime H.A. "Welcome to France's New War on Terror in Africa: Operation Barkhane," August 7, 2014. The National Interest. Accessed November 26, 2014. http://national interest.org/feature/welcome-frances-new-war-terror-africa-operation-barkhane-11029.

Roberge, Michal and Youkyung Lee, “China-Tawian Relations.” Council on Foreign Relations. Last modified August 11, 2009, accessed April 09, 2015.

Tempest, Mark. “China’s Sea Lanes.” U.S. Naval Institute Blog, January 2009. Accessed April 15, 2015. http://blog.usni.org/2009/01/03/chinas-sea-lanes/.

The University of Texas. Perry-Castañeda Library Map Collection. March 25, 2009. Accessed April 16, 2015. http://www.lib.utexas.edu/maps/middle_east_and_asia/china_first _and_second_island_chains_2009.jpg.

Wang Guanqun. “35,860 Chinese Evacuated from Unrest-Torn Libya.” Xinhuanet, March 3, 2011. Accessed December 3, 2014. http://news.xinhuanet.com/english2010/china/201103/03/c_13759456.htm.

梁军. “China Evacuates Nationals from Chaotic Libya.” People’s Daily Online. Accessed December 3, 2014. http://en.people.cn/90001/90776/90883/7296633.html.

Other Sources

Button, Robert, John Gordon IV, Jesse Riposo, Irv Blickstein, and Peter A. Wilson. Warfighting and Logistic Support of Joint Forces from the Joint Sea Base. Santa Monica, CA: RAND, National Defense Research Institute, 2007.

Chase, Michael S., Jeffrey Engstrom, Tai Ming Cheung, Kristen A. Gunness, Scott Warren Harold, Susan Puska, and Samuel K. Berkowitz. China's Incomplete Military Transformation: Assessing the Weaknesses of the People's Liberation Army (PLA). Santa Monica, CA: RAND, National Defense Research Division, February 2015. Accessed February 12, 2015. http://www.rand.org/pubs/research_reports/RR893.html. 
Daly, John C.K. “Counterterrorism or Neo-Colonialism? The French Army in Africa.” Terrorism Monitor 12, no.5 (March 06, 2014). Accessed April 09, 2015. http://www.jamestown.org/regions/africa/single/?tx_ttnews\%5Btt_news\%5D=42051\&tx _ttnews\%5BbackPid\%5D=55\&cHash=8e372fe5ecd8a63b4cfccecb1544d46e\#.VScWh_n F9Ok

Hundley, Richard O. Past Revolutions, Future Transformations: What Can the History of Revolutions in Military Affairs Tell Us about Transforming the U.S. Military?. Santa Monica, CA: RAND, 1999. Accessed October 18, 2014. http://www.rand.org/content/ dam/rand/pubs/monograph_reports/2007/MR1029.pdf.

Moulton, Christopher A., David T. Orletsky, Michael Kennedy, and Fred Timson. Reducing Long-Term Costs While Preserving a Robust Strategic Airlift Fleet: Options for the Current Fleet and Next-Generation Aircraft. Santa Monica, CA: RAND, Project Air Force, 2013. Accessed December 9, 2014. http://www.rand.org/content/dam/rand/pubs/ monographs/MG1200/MG1238/RAND_MG1238.pdf.

Pirnie, Bruce R. and William E. Simons, Soldiers for Peace: An Operational Typology, Guidelines for U.S. Involvement in Peace Operations (Santa Monica, CA: RAND, National Defense Research Institute, 1996). Accessed November 4, 2014. http://www.rand.org/pubs/monograph_reports/MR582.html..

Pirnie, Bruce R., and William E. Simons. Soldiers for Peace: Critical Operational Issues. Guidelines for U.S. Involvement in Peace Operations. Santa Monica, CA: RAND, National Defense Research Institute, 1996.

Shurkin, Bruce R. France's War in Mali: Lessons for an Expeditionary Army. Santa Monica, CA: RAND, National Defense Research Institute, 2014. Accessed November 6, 2014. http://www.rand.org/pubs/research_reports/RR770.html. 